Syracuse University

SURFACE

April 2007

\title{
Cite Unseen: How Neutral Citation And America's Law Schools Can Cure Our Strange Devotion To Bibliographical Orthodoxy And The Constriction Of Open And Equal Access To The Law
}

Ian Gallacher

Syracuse University College of Law, igallach@law.syr.edu

Follow this and additional works at: https://surface.syr.edu/lawpub

Part of the Law Commons

\section{Recommended Citation}

Gallacher, Ian, "Cite Unseen: How Neutral Citation And America's Law Schools Can Cure Our Strange Devotion To Bibliographical Orthodoxy And The Constriction Of Open And Equal Access To The Law" (2007). College of Law - Faculty Scholarship. 2.

https://surface.syr.edu/lawpub/2

This Article is brought to you for free and open access by the College of Law at SURFACE. It has been accepted for inclusion in College of Law - Faculty Scholarship by an authorized administrator of SURFACE. For more information, please contact surface@syr.edu. 


\title{
CITE UNSEEN: HOW NEUTRAL CITATION AND AMERICA'S LAW SCHOOLS CAN CURE OUR STRANGE DEVOTION TO BIBLIOGRAPHICAL ORTHODOXY AND THE CONSTRICTION OF OPEN AND EQUAL ACCESS TO THE LAW
}

\author{
Ian Gallacher*
}

I. Introduction

There can be fewer subjects less inviting, on their face, than a discussion of legal bibliographical practice. Citation itself is neither scholarship nor analysis but is the mere act of recording a supporting source's location; ${ }^{1}$ the quintessence of form, with no intrinsic substance at all. It is the recorded source that matters, one would think, not its citation.

And yet citation plays a much more important role in the American legal system ${ }^{2}$ than this modest description might lead one to believe. ${ }^{3}$ Competence in legal

\footnotetext{
Assistant Professor of Law, Syracuse University College of Law. An early version of this article was presented as a paper at the "Too Pure An Air: Law And The Quest For Freedom, Justice, And Equality" conference in June 2006, co-sponsored by Texas Wesleyan University School of Law and the University of Gloucestershire. Thanks to Dean Hannah Arterian for her support in making this article possible, to Penny Pether for her willingness to talk through some of the issues this article raises, and to Thuy Le, Syracuse University College of Law class of 2007, who put up with difficult to decipher requests for research assistance with skill, patience, and good humor. Thanks also to the legal research and writing teachers across the country who responded to my requests for information about citation instruction. Some individual responses are credited throughout the course of this article but all responses were helpful in giving me a picture of the way legal citation is taught in law schools today. I owe a particular debt of gratitude to Chancellor Nancy Cantor of Syracuse University, whose vision of engaged scholarship and of the university as a public good have inspired much of the work in this article. And thanks, as always, to Julia McKinstry.

1 Paul Axel-Lutte has described the twin purposes of a legal citation as follows: "First, it indicates the nature of the authority upon which a statement is based. Second, it contains the information necessary to find and read the cited material." Paul Axel-Lute, Legal Citation Form: Theory And Practice, 75 LAW LiBR. J. 148, 148 (1982).

2 This phenomenon appears to be limited to America or, at least, to be most prevalent here. Penelope Pether notes that "[n]ot only do the English lack a uniform system of citation (most law periodicals produce brief and idiosyncratic guides for contributors) but it is also possible to find within as well as among the journals significant variations in citation form." Penelope Pether, Discipline and Punish: Dispatches from the Citation Manual Wars and Other (Literally) Unspeakable Stories, 10 GRIFFITH L. REV. 103, 104 (2001).

3 One commentator has noted that " $\mathrm{t}]$ he importance of citations in American jurisprudence can hardly be overstated." Vickie Rainwaite, Citation Form In Transition: The ALWD Citation Manual, 7 TEX. WeSLEYAN L. REv. 21 (2000)(book review).
} 
citation is expected of the most junior attorneys, ${ }^{4}$ and an ability to generate accurate citations is viewed as a proxy for a lawyer's attention to detail. ${ }^{5}$ Some argue that correct citation "adds to the credibility of the author," and that "[a]ttention to citation form ... will improve the reader's sense of reliability, credibility, and integrity when evaluating the worth of a document and the writer's professionalism." 6 Others note that "in our legal culture, attention to detail, even in citation form, is a sign of excellence." 7

Courts have an ambivalent relationship with legal citation. On the one hand, more than a quarter of judges polled in a recent survey identified citation errors as "a common problem in legal writing." 8 Many of those judges indicated that the absence of citation mistakes is the most important formatting element in documents they review. ${ }^{9}$ Judges are critical of practitioners ${ }^{10}$ for not following

4 See, e.g., MARK HERRMANN, The CURMUdGEON's Guide To PRACTICING LAW 1 (2006)(In a fictional memorandum to a new associate, Herrmann (a partner at Jones, Day in Cleveland), makes three assumptions about all written work. "First, it will contain no typographical errors. Second, it will contain no grammatical errors. Third, all citation forms will be correct.") In the interests of full disclosure, the author's endorsement of Herrmann's book appears on its introductory pages.

$5 \quad$ "Every lawyer needs to know proper citation form. Sloppy or inaccurate form suggests inattention to detail or ignorance of the correct form." Susan W. Fox, Citation Form: Getting It Right, 74 Fla. B.J. 84 (2000). See also, Michael R. SMith, AdVANCEd Legal Writing: TheOries AND STRATEGIES IN PERSUASIVE WRITING 169 (2002)(identifying the careful and full compliance with applicable citation rules in the citation of authorities as one the ways a legal writer can be "a more persuasive advocate in terms of both logos and ethos.")

6 Timothy D. Blevins, A Hallmark of Professional Writing Form, 29 T. MARSHALl L. ReV. 89, 95 (2003).

7 Nancy A. Wanderer, Citation Excitement: Two Recent Manuals Burst On The Scene, $20 \mathrm{ME}$. B.J. 42, 46 (2005), citing Carol Bast et al, Has The Bluebook Met Its Match? The ALWD Citation Manual, 92 LAW LiBR. J. 337, 338 (2000).

$8 \quad$ Susan H. Kosse \& David ButleRitchie, How Judges, Practitioners, And Legal Writing Teachers Assess The Writing Skills Of New Law Graduates: A Comparative Study, 53 J. LeGAL EduC. 80,85 (2003)(revealing that $28.2 \%$ of judges polled had found citation errors to be a common problem).

$9 \quad I d$., at 90 . Of the state judges polled $22.2 \%$, and $16.7 \%$ of the federal judges, felt that "no citation mistakes" was the most important element of formatting. The importance these judges placed on citation accuracy can be most readily perceived when compared with their other answers. While compliance with court rules was the most important formatting element to both sets of judges ( $42.6 \%$ of state judges and $38.9 \%$ of federal judges), and state judges ranked the absence of grammar mistakes as being a more important formatting element (29.6\%), the federal judges ranked the absence of citation and grammar mistakes as being equally important $(16.7 \%)$, and both sets of judges ranked the absence of citation errors as being more important than the absence of punctuation (7.4\% state judges and $5.6 \%$ federal) or spelling errors $(9.3 \%$ state judges and $11.1 \%$ federal). Id.

10 Courts will sometimes even criticize each other for their citation practices. In Thorne v. Jones, 765 F.2d 1270, 1275 (5th Cir. 1985), the Fifth Circuit takes a very genteel jab at the Supreme Court for placing a comma after a court abbreviation and before the "at" of a pinpoint citation. "Pell v. Procunier, 417 U.S., [sic] at 823, 94 S.Ct., [sic] at 2804." 
proper citation form, ${ }^{11}$ and are willing to impose citation requirements for documents filed in their courts, ${ }^{12}$ and many are unwilling to have citation requirements imposed on them, citing an invasion of judicial independence ${ }^{13}$ or administrative inconvenience. ${ }^{14}$

11 See, e.g., Batter Boy Bakery v. Corn, 420 N.E.2d 1360, 165 (Ind. App. 1981)(criticizing counsel for using "improper citation form"); Bradshaw v. Unity Marine Corp., 147 F.Supp. 2d 668, 670-71 (S.D.Tex. 2001)(“. . Plaintiff 'cites' to a single case from the Fourth Circuit. Plaintiff's citation, however, points to a nonexistent 'Volume 1886' of the Federal Reporter Third Edition and neglects to provide a pinpoint citation for what, after being located, turned out to be a fortypage decision."); In re Shepperson, 674 A.2d 1273, 1274-75 (Vt. 1996)(suspending lawyer for, among other things, "citation errors that make identification of the case difficult."), cited by Judith D. Fischer, Bareheaded and Barefaced Counsel: Courts React To Unprofessionalism In Lawyers' Papers, 31 SuffolK U. L. ReV. 1, 30 (1997).

12 Ten state court systems require citations to conform to The Bluebook or some other style manual: Alabama (either Bluebook or ALWD; Ala. R. App. P. 28(a)(10)); California (Bluebook or California Style Manual; Cal. R. Ct. 313(c) \& (g)); Delaware (Bluebook; Del. Sup. Ct. R. 14(g)); Florida (Bluebook; Fla. R. App. P. 9.800); Idaho (either Bluebook or ALWD; Sup. Ct. Idaho Internal R. 15(e)(amended 2005)); Indiana (Bluebook; Ind. R. App. P. 22); New Mexico (Bluebook; N.M. Sup. Ct. Gen. R. 23-112); North Carolina (Bluebook, but specifically the 14th edition; N.C. R. App. P. App. B.); Texas (Bluebook or the Texas Rules of Form; Tex. Loc. R. 4th Ct. App. 8 (2004 update)); Washington (Bluebook; Wash. Ct. R. Gen. App. GR 14). In addition the United State Court of Appeals for the Eleventh Circuit requires citations to follow the requirements of the Bluebook or the ALWD Manual (11th Cir. R. 28-1(k)) as does the United States District Court for the District of Montana (D. Mont. R. 10-4). Federal courts requiring citations to adhere to Bluebook format alone are the United States District Court for the District of Delaware (D. Del. R. 7.1.3(F)) and the Court of Appeals for the Armed Services (U.S. Ct. App. Armed Servs. R. Prac. \& Proc. 37(c)(2)). For a list of court-specific citation requirements, see ALWD Citation MANual: A Professional System of CitATion, Appendix 2 (Darby Dickerson, ed. 3d ed. 2006).

13 See, e.g., Letter from the Honorable Leonie M. Brinkema, Judge, United States District Court for the Eastern District of Virginia, to Joan Countryman, Appellate Court and Circuit Administration Division, Administrative Office of the U. S. Courts (March 5, 1997), available at http:// www.hyperlaw.com/jccite/006.txt (last visited May 11, 2006)(“To my knowledge, no federal judge is required to follow any particular form for his or her opinions. Some judges value brevity; some use literary flourishes; some include many footnotes, others use few; some follow Blue Book [sic.] format, others do not; some only cite to the official source, and others include parallel cites. To mandate that judicial opinions conform to a specific format, such as numbering every paragraph and including parallel cites to electronic publications, seriously invades judicial independence.") I have, wherever possible, used the internet citation for materials referred to in this article in an attempt to highlight the ubiquity of materials relevant to legal researchers on the internet and the ease of citation to those materials. This is not, however, an intentional violation of The Bluebook's Rule 18.2 ("When information is available in a traditional printed source or on a widely available commercial database, it should be cited to that source rather than to the Internet"), since the internet information cited to here is not, for the most part, otherwise available. Judge Brinkema's position, and the problems with it, will be discussed in more depth infra. See, footnotes 156 to 165 and accompanying text.

14 See, e.g., Letter from the Honorable Alfredo C. Marquez, Senior Judge, United States District Court for the District of Arizona (March 3, 1997), available at

http:/ / www.hyperlaw.com/marquez.pdf (last visited May 11, 2006)(“the proposed [neutral] 
But on the other hand, judges might be more tolerant about new citation formats than the data suggest. Two studies by Robert Berring and Kathleen VandenHeuvel found that courts were more relaxed about allowing new citation formats than the researchers had anticipated, "requiring only that the citing party provide a copy of the printout to all parties." 15

Orthodox legal citation has perhaps its most powerful effect on law students. Legal citation is typically taught to first year law students by their legal writing teachers ${ }^{16}$ and can take up a considerable part of the legal writing curriculum. ${ }^{17}$ Even where class time is not taken up by citation study, products such as the Interactive Citation Workstation, published by LexisNexis and available online as part of a law student's subscription to the LexisNexis Total Research System, can occupy a considerable amount of time for a first year law student. ${ }^{18}$ And this

citation form is burdensome, cumbersome, and unnecessary" and citing burden to clerks with responsibility of assigning docket numbers to court orders under proposed system.)

15 Robert Berring, On Not Throwing the Baby: Planning the Future of Legal Information, 83 CAL. L. ReV. 615, 630-31 (1995).

$16 \quad$ Pamela Lysaght \& Grace Tonner, Bye-Bye Bluebook? 79 Mich. B.J. 1058, 1058 (2000). 17 Responses to a request for information on the amount of time devoted to a study of legal citation ranged from twenty minutes (E-mail from Ruth Anne Robbins, Clinical Associate Professor of Law, Rutgers School of Law - Camden, to author (May 7, 2006, 17:38 (DST)(on file with author)) to eight hours (E-mail from Eric Easton, Professor of Law and co-director of Legal Skills Program, University of Baltimore School of Law, to author (May 6, 2006, 12:19 (DST)(on file with author)). These amounts of time are perhaps slightly misleading; when little class time is used on citation instruction, students are often directed to alternative sources of information, such as the Interactive Citation Workstation (infra., n.18), in order to hone their citation skills, and when a large block of time is allocated to citation instruction, that likely includes all time devoted to the subject, including labs. and workshops offered by teaching assistants.

18 While the Interactive Citation Workstation appears online, there is also a book version, published by LexisNexis. Tracy L. McGaugh, Et Al., Interactive CitATION WORKBOOK For THE BLUEBOOK: A UNIFORM SYSTEM OF CiTATION AND ALWD CiTATION MANUAL (2005). Numerous other materials exist, in print and on the internet, to help law students understand legal citation and to help them create citations that conform with Bluebook or ALWD citations rules. See, e.g., Alan L. DWORSKy, User's Guide to The BluebooK (2006); Peter W. Martin, Introduction to Basic Legal Citation, available at http:/ / www.law.cornell.edu/citation (last visited, July 13, 2006); Ronald B. Standler, Legal Research and Citation Style in USA, available at http://www.rbs0.com/lawcite.htm (last visited, July 13, 2006); the LegalCitation StyleGuide [sic], available at http:/ / www.legalcitation.net (last visited July 13, 2006). Many legal writing textbooks also contain sections instructing students on citation form. See, e.g., RICHARD K. NEUMANN, JR. LEGAL REASONING AND WRITING: STRUCTURE, STRATEGY, AND STYLE, 251-67 (5th ed. 2005); Charles R. CALleros, LegAl Method AND WRITING, 281-301 (5th ed. 2006); LindA H. EdWARdS, LEGAL WRITING: PROCESS, ANALYSIS, AND ORGANIZATION, 185-205 (4th ed. 2006); ROBIN WellFord Slocum, Legal ReAsoning, Writing, AND PERsuAsive ARGUMENT, 263-84 (2d ed. 2006). One commercially-produced software program even promises to "automate[ ] legal citation so you can insert accurate properly-formatted citations into your document with a single click." CiteIt! Version 3 - Legal Research and Citation Made Simple available at http://www.citeit.com/trial (last visited July 13, 2006). After test of a previous version of this 
is time obtained at a cost. Robert Berring has observed that the Bluebook, ${ }^{19}$ for many years the only legal citation manual and still self-styled as "the definitive guide for legal citation in the United States," 20 "has inflicted more pain on more law students than any other publication in legal history." 21

But the pain involved in learning how to cite legal information correctly ${ }^{22}$ has its perceived rewards. Mastery of legal citation is, for many students, the passport to membership in the elite world of law reviews. ${ }^{23}$ And because participation in a law review or journal during law school is often thought of as a stepping-stone to an employment offer from a desirable legal employer after graduation from law school, ${ }^{24}$ the pressure to become a member of law review is intense. ${ }^{25}$

software, bundled with a previous edition of The Bluebook, suggests that this product's claims are, at best, optimistic.

19 The Bluebook: A Uniform System of CitATION (Columbia Law Review Ass'n et al. eds., 18th ed. 2005) ("Bluebook").

$20 \quad I d$. The Bluebook's hegemony has most recently been challenged by a manual produced by the Association of Legal Writing Directors ("ALWD”). ALWD CitATION MANUAL: A PROFESSIONAL SYSTEM OF CiTATION (Darby Dickerson, ed. 3d ed. 2006)(“ALWD Manual”). A discussion of the development of these two manuals, as well as the manual developed by students at the University of Chicago Law School, is included infra. at notes 67 - 94 and accompanying text.

21 Robert BerRing, INTROduction to The BlueboOK: A SiXTY-Five YEAR Retrospective at $\mathrm{v}(1988)$.

22 The Bluebook has been charitably described as "[n]otoriously tedious, hard to use, and ever-changing. ..." Wayne Schiess, Meet ALWD: The New Citation Manual, 64 TEX. B.J. 911, 911 (2001). And The Bluebook itself recognizes that it can "often be intimidating for new users." Bluebook, supra n.19, at 1 .

23 See, e.g., Michael Bacchus, Comment, Strung Out: Legal Citation, The Bluebook, And The Anxiety Of Authority, 151 U. PA. L. REV. 245, 245-46 (2002)(describing the process of the University of Pennsylvania's "writing competition" as being primarily one of requiring first year law students to "rewrite footnotes and citations ... to conform to the dictates of The Bluebook" and describing the Bluebook as "a foundational text upon which legal culture is built.") 24 See, e.g., E. Joshua Rosenkrantz, Law Review's Empire, 39 Hastings L. J. 859, 907 (1988)("Students' careers turn on the fortuity of law review membership. . . All employers, or at least all those who interview on campus, assume the law review to be valuable.") These assumptions might not be valid. A recent study of University of Chicago graduates suggested that law review membership does not "correlate with higher salaries after controlling for grades," and suggested that law review board members had lower salaries than their non-board member colleagues. Dexter Samida, The Value Of Law Review Membership, 71 U. CHI. L. REV. 1721, 1725 (2004).

25 See, e.g., Nancy J. Soonpa, Stress In Law Students: A Comparative Study Of First-Year, Second-Year, And Third-Year Students, 36 CONN. L. REV. 353, 367 (2004)(citing law school grades as a source of anxiety or stress, in part, because "law school grades can affect ... the ability to become a law review member.") Although the importance of law review membership might be exaggerated by law school students, many believe law review membership to be the single most important facet of a law student's career in law school. See, e.g., J. SELIGMAN, THE High CiTADEL, 178-79 (1978), quoted by, Scott M. Martin, The Law Review Citadel: Rodell Revisited, 71 IowA L. REV. 1093, 1103(1986)(“[a]t Harvard Law School, the fate of a student's law school career is 
Legal citation also plays a significant role in the institutional battle over the status and power of legal research writing teachers. Scholars have used revolutionary rhetoric to describe the significance of the Association of Legal Writing Director's decision to offer an alternative to the Bluebook, ${ }^{26}$ and the conflict between, on the one hand, doctrinal ${ }^{27}$ faculty and legal writing faculty and, on the other hand, legal writing faculty and students, has been explored in the scholarly literature. ${ }^{28}$ The importance of citation to legal writing teachers can be seen by the rhetorical choice to include "professional" in the ALWD Manual's subtitle ${ }^{29}$ in order to distinguish it from The Bluebook's use of "uniform;" 30 the inherent messages of competence and ownership of the citation process coiled into the word choice demonstrate that legal writing teachers consider themselves to be the experts in the legal citation field.

For many groups in the legal community then, legal bibliography has assumed an importance that seems out of proportion to its narrowly-defined function as a tool to describe the nature and location of source material. In fact, if it is possible to see the American legal system in quasi-religious terms, with lawyers as its

largely determined during two weeks in the first year. Although second- and third-year grades are important to potential employers, their value is diminished by the omnipresence of Law Review.")

$26 \quad J u l i e$ Cheslik, The Battle Over Citation Form Brings Notice To LRW Faculty: Will Power Follow?, 73 UMKC L. REV. 237, 242(2004)(“Every student of history knows that revolutions do not come about due to any one, single factor. ... Thus ... it is probably an oversimplification to say that the uprising of legal writing directors showing their collective muscle was caused by their dissatisfaction with The Bluebook."); Alex Glasshauser, Citation and Representation, 55 VAND. L. REV. 59, 60 (2002)(“[t]hrough the lens of the American Revolution, this Article traces the roots of the citation uprising. ..."); Jennifer L. Cordle, ALWD Citation Manual: A Grammar Guide To The Language Of Legal Citation, 26 U. ARK. LiTTLE ROCK L. REV. 573, 573 (2004)(“Sides were taken revolutionaries supported the adoption of the [ALWD Manual], ... and loyalists remained true to the Bluebook.")

$27 \quad$ A term used to describe those teaching traditional law school casebook courses, such as torts, property, and contracts. It used to be possible to distinguish these faculty members from legal writing teachers by speaking of tenure-track and non tenure-track teachers, but enough legal writing teachers are now on the tenure-track, or are themselves tenured, that this distinction no longer carries any meaning.

28 See, e.g., Cheslik, supra n.26, at 237-38(concluding that "legal research and writing faculty are mistaken if they believe that the war to garner respect, status, and power within the academy is being won by engaging in the battle to control citation form."); Eric Shimamoto, Comment, To Take Arms Against A See Of Trouble:. . . Legal Citation And The Reassertion Of Hierarchy, 73 UMKC L. REV. 443, 444 (2004)(arguing that "the attempt by legal writing professors to wrest control of legal citation form from law students is a blatant expression of the most obvious form of hierarchical control in legal education.")

$29 \quad$ ALWD Manual, supra n.20.

30 Bluebook, supra n.19. 
priests, ${ }^{31}$ then the Bluebook, which is sometimes referred to as the "Bible" of legal citation ${ }^{32}$ can be seen as the principle text of a cult-within-a-cult, with its own clearly defined stages of indoctrination, ${ }^{33}$ doctrinal schisms, ${ }^{34}$ heretics, 35 and even, possibly, martyrs, both figurative ${ }^{36}$ and literal. ${ }^{37}$

\section{Perhaps, though, our contemporary devotion to citation orthodoxy is an atavistic reversion to more pagan beliefs. Penelope Pether has spoken of the "fetishization of citation" in this country ${ }^{38}$ and she might be on the right track. A}

31 See, e.g., Robert K. Vischer, Heretics in the Temple of the Law: The Promise and Peril of the Religious Lawyering Movement, 19 J. L. \& RELIGION 427, 427 (2004)(arguing that priests' role as mediators between God and man "has been taken by lawyers, who provide access to our common framework of legal rights and privileges.") 32 Jonathan Jacobson, A Uniform System of Citation, 43 BROOKLYN L. REV. 826, 826 (1977)(book review); Wanda M. Temm, New Kid On The Block: The ALWD Citation Manual, 59 J. Mo. B. 16, 16 (2003). The Constitution is, of course, another Bible in this secular religion. See, Christopher E. Smith, Law and Symbolism, 1997 Detroit C. L. AT Mich. StATE U. L. Rev. 935, 93738 (1997)(describing Constitution as a "sacred text").

33 From initiates (first year law students) to priests (those students working on law reviews and journals, ) to high priests (those working on the Bluebook-editing law reviews of Harvard, Columbia, Pennsylvania, and Yale).

$34 \quad$ The tension between the Bluebook and the ALWD Manual comes readily to mind, with the introduction of the ALWD Manual having an almost Reformation-like impact on the previously settled world of legal bibliography.

35 "In 1986, Judge Richard Posner proclaimed himself a leading heretic by bidding "Goodbye to the Bluebook." Jim C. Chen, Something Old, Something New, Something Borrowed, Something Blue, 58 U. CHI. L. REV. 1527, 1527 (1991)(book review).

36 In many schools, the introduction of the ALWD Manual led to student protests that they would be unprepared for entry into the real world of legal citation, dominated (in the students' eyes, at least) by the Bluebook. Rumors that these protests might have caused some legal writing teachers to lose their positions have circulated in legal writing circles but are, as with most rumors, unverifiable. Pether offers an example of the passions that citation manuals can generate: "A legal writing director in contract employment who provides the sole income support for a disabled spouse and three children was bullied by her law school's administration to abandon ... [the ALWD Manual] ... after a candidate for the law school's student bar association presidency campaigned successfully on the platform that she would be forced to do so." Penelope Pether, Negotiating the Structures of Violence: or, On Not Inventing "The Sullivans," 15 SOCIAL SEMIOTICS 5, 25 (2005). Under such circumstances, it is perhaps understandable that the affected individuals choose not to go on the record.

37 At least one capital punishment appeal appears to have been decided based on the Supreme Court's interpretation of a bibliographical signal, "cf," and the signal's meaning in the context of the prisoner's brief. Lambrix v. Singletary, 520 U.S. 518 (1997). See, Ira Robbins, Semiotics, Analogical Reasoning, and the Cf. Citation: Getting Our Signals Uncrossed, 48 DuKE L. J. 1043, 1045-46 (1999)(using the Lambrix decision as the basis for a discussion of the ways in which courts have interpreted, and misinterpreted, the cf. signal when used in briefs.) Cary Lambrix, the petitioner in the 1997 Supreme Court case, is still on Florida's death row awaiting execution. Available at http://www.dc.state.fl.us/ActiveInmates/Detail.asp?Bookmark=1\&From= list\&SessionID=410078224 (last visited May 11, 2006).

38 Pether, Discipline and Punish supra n.2, at 106. My borrowing of this term renders me uncouth in Professor' Berring's eyes. He has opined that only a "complete boor might venture to 
fetish is, after all, "[a]n inanimate object reverenced as having magical powers" 39 and many law students and lawyers certainly ascribe at least quasi-magical powers to legal citation. ${ }^{40}$ Law students, for example, believe that command over legal citation will bring them riches and professional success, by allowing them admittance into the elite circle of law review members that will, in turn, give them access to prestigious and well-paying legal employment, ${ }^{41}$ legal scholars believe that citation to their work results in an increase in their reputation and prestige, ${ }^{42}$ lawyers believe that judges will think them competent and credible if they use correct citation form, and judges believe that the provision of a citation transubstantiates a mere "unpublished opinion" into an "the law." 43 There is no better example of magic thinking in legal culture than this.

say that the Uniform System of Citation has made a fetish of citation form. ..." Berring, Introduction, supra n.19, at vi. To which I can only plead that I am guilty as charged. It is interesting to note that Professor Berring almost stepped over the line himself when he noted that "for some, proper citation form is almost a fetish." Berring, supra n.15, at 629.

39 THE NEW SHORTER OXFORD ENGLISH DictiONARY, 938 (1993). I do not, however suggest that another alternative meaning of the word - "an object [or] action acting as a focus for sexual desire" (id.) - has any application here, although I note, without further comment, the description of The Bluebook as the "Kama Sutra" of legal citation. Peter Lushing, A Uniform System Of Citation, 67 ColuM. L. Rev. 599, 599 (1967)(book review). Perhaps it was this alternative meaning that caused Professor Berring such concern.

40 Pether's anthropological insight is matched by Judge Posner, who has also drawn from the world of anthropology to discuss the Bluebook's role in contemporary legal culture. See, Richard A. Posner, Goodbye to The Bluebook, 53 U. CHI. L. REV. 1343, 1343 (1986(book review)("Anthropologists use the word 'hypertrophy' to describe the tendency of human beings to mindless elaboration of social practices. The pyramids in Egypt are the hypertrophy of burial. The hypertrophy of law is A Uniform System of Citation....") The use of the same discipline to describe the same phenomenon by Pether and Posner, two scholars whose views are otherwise so different that they would seem only to share the first letter of their last names, suggests that anthropologists might have a great deal to tell us about the law and its practices.

41 See, e.g., Michael Long, Winning Isn't The Only Thing: Is Bar Membership A License To Abuse Others, 59 OR. ST. B. BULL. JAN. 1999, at 15-16 ("the top 5 to 10 percent of our class will be extended offers to join law review, pursue prestigious clerkships and ultimately be considered for lucrative legal employment.")

42 See, e.g., William M. Landes et al, Citations, Age, Fame, And The Web, 29 J. LeGAL STUD. 319 (2000)(reviewing Fred Shapiro's study of scholarly and popular reputations of legal scholars by looking at the frequency of citation to their work.); Arthur D. Austin, Footnotes As Product Differentiation, 40 VAND. L. REV. 1131, 1135 (1987)(describing citation in scholarly work as "subtle, but critical, influence in the determination of promotion, tenure, and professional status.") Authors who post their work on electronic distribution websites like the Social Science Research Network and the Bepress Legal Repository (a service associated with ExpressO, the internetbased service many legal scholars now use to submit their work to law reviews) get regular updates on the number of full-text downloads, presumably so they can point to the level of interest in their work even at a pre-publication stage.

43 For a critique of the practice of the Courts of Appeal issuing unpublished opinions, see, Penelope Pether, Take A Letter Your Honor: Outing The Judicial Epistemology Of Hart v. Massanari, 
In this article, I will examine the undesirable effects of this devotion to citation form, and in particular the unintended, but real, effect the present citation system has in impeding free and open access to the law. This effect has been noted previously ${ }^{44}$ but is becoming more significant as the cost of legal information in book form rises ${ }^{45}$ and it becomes more likely that, sooner rather than later, the only method of retrieving, studying, and using the common law will be through the vast commercial databases maintained by West and LexisNexis.

This article will review the history of legal citation, then move to a discussion of how citation rules affect our ability to cite to court opinions, and then will look more closely at some proposed alternatives to present citation practices and the reasons those alternatives have not, as yet, become standard. I will not be engaging in a comparative critique of the ALWD Manual and The Bluebook; that discussion has been conducted elsewhere, with the balance of the debate favoring the ALWD Manual. ${ }^{46}$ Nor will I criticize The Bluebook's tendency to

62 Wash. \& LeE L. ReV. 1553 (2005); Penelope Pether, Inequitable Injunctions: The Scandal Of Private Judging In The U.S. Courts, 56 STAN. L. REV. 1435 (2004).

$44 \quad$ See, e.g., James H. Wyman, Freeing The Law: Case Reporter Copyright And The Universal Citation System, 24 FLA. ST. U. L. REV. 217 (1996);

45 Costs for print materials must include both the costs of the materials themselves and the costs of storing those materials in a way that allows for convenient retrieval of the information contained within them. For example, a medium sized collection of new core materials (primary materials such as reporters plus digests and other secondary materials) for a law firm in a large state could run to approximately $\$ 60,000$, with approximately $\$ 30,000$ in annual supplementation fees. See, e.g., Ian Gallacher, Forty-Two: The Hitchhiker's Guide to Teaching Legal Research To The Google Generation, 39 U. AKR. L. REV. 151, 193-196 (2006) (quoting KENDALL SVENGALIS, LEGAL INFORMATION BUYER'S GUIDE AND REFERENCE MANUAL 25-27 (2005). Once costs for housing the collection are considered, an annual cost of at least $\$ 100,000$ for print-based legal information materials would not be unreasonable. Gallacher, 39 U. Akr. L. Rev. at 196. Supplementation costs for print-based legal information materials are rising dramatically. In 1993, Am. Jur. 2d costs $\$ 1,300$. Id. at 195 . By 2001, the costs has risen to $\$ 3,058.75$, and in 2005 the figure was $\$ 4,560.75$. Id.

$46 \quad$ See, e.g., K. K. DuVivier, Legal Citations for the Twenty-First Century, 29 Colo. LAW 45 (2000); Thomas R. Haggard, Citing News! 12 S. CAR. LAW. 12 (2000); Pamela Lysaght \& Grace Tonner, Bye-Bye Bluebook?, 79 Mich. BAR. J. 1058 (2000); Wayne Schiess, Meet ALWD: The New Citation Manual, 64 TEX. B.J. 911 (2001); Alex Glasshauser, Citation and Representation, 55 VAND. L. ReV. 59 (2002); Wanda M. Temm, New Kid on the Block: The ALWD Citation Manual, 59 J. Mo. B. 16 (2003); Suzanne E. Rowe, The Bluebook Blues: ALWD Introduces a Superior Citation Book for Lawyers, 64 OR. ST. B. Bull. 31 (2004); Jennifer L. Cordle, ALWD Citation Manual: A Grammar Guide to the Language of Legal Citation, 26 U. ARK. LiTTLE ROCK L. REV. 573 (2004); Nancy A. Wanderer, Citation Excitement: Two Recent Manuals Burst on the Scene, 20 ME. B.J. 42 (2005). The number of articles about the ALWD Manual should come as no surprise: the Manual was published at a time when legal writing teachers are becoming increasingly interested in writing and publishing articles about their discipline, and the Association of Legal Writing Directors was vocal about the importance of disseminating information about the ALWD Manual as broadly as possible. Posting of Heather Macfarlane to LWIONLINE (June 3, 2002). The fact that these 
change the way it requires authors to use signals such as See or Cf. That issue has also been engaged by other scholars ${ }^{47}$ and, while thought-provoking, is tangential to my purpose here.

In this article, I will conclude that the American legal system's present citation practices have the real, if unintended, consequence of solidifying two for-profit companies' preeminent positions as the provider of American legal information, and that America's law schools should act to correct this situation and make the law freely available to all.

\section{Why Open Access To The Law Is Important}

Before we begin to discuss how open access to the law should be accomplished, however, we should first consider whether this is a desirable result. Providing open access the law might be the legal equivalent of opening Pandora's box, permitting indiscriminate use that might, in some cases, cause more harm than good.

And I should be clear at the outset that we have, at present, relatively open access to the law for all who are interested in reading and using it. Robert Berring argued, in 1995, that "the United States has the world's best legal information system.... [I]t is possible for any literate, English-speaking person to walk into a local library, perhaps one that specializes in the law, but perhaps not, and find federal and state court cases, statutes, and administrative law." 48

The situation was likely never as rosy as that portrayed by Berring, ${ }^{49}$ and there can be no doubt that the situation is worse now than it was when Berring wrote his article. ${ }^{50}$ Nonetheless, for many citizens, some means of accessing the law still exists. My concern here is the way in which the increasing reliance on digital

articles all favor the ALWD Manual is also unsurprising. Many of these articles were written by legal writing teachers, most of whom likely appreciate the value of the ALWD Manual as a teaching tool.

47 See, e.g., Ira Robbins, Semiotics, Analogical Reasoning, and the Cf. Citation: Getting Our Signals Crossed, 48 DuKE L.J. 1043 (1999); A. Derby Dickerson, An Un-Uniform System of Citation: Surviving With the New Bluebook, 26 STETSON L. REV. 53 (1997).

$48 \quad$ Berring, supra n.15, at 618.

49 Not everyone lives within walking distance of a library of any sort, and many live a considerable distance away from the types of library described by Berring. And not all libraries, especially in economically-disadvantaged parts of the country, were as well-stocked with legal materials as Berring's description might lead an observer to believe, even back in 1995.

50 The costs of maintaining a comprehensive print-based collection of legal information materials have increased dramatically since 1995. See, supra at n.45. 
storage of, and access to, legal information will restrict that access ${ }^{51}$ and with ways the internet can help to make the law available to everyone.

Of course, access alone is not enough for non-lawyers seeking to read and understand court decisions. Legal information is undeniably complicated; it is difficult to find, difficult to interpret, and difficult to contextualize. Many books have been written explaining how lawyers go about the process of finding the law relevant to a particular legal issue, ${ }^{52}$ but even before lawyers (and law students) can go through the mechanical steps to find case law articulating the rules that will help them to predict a court's future decisions or to help influence that court's decision, they must first understand what the legal issues are. This process is at the heart of why people go to law school, and is therefore at the heart of what makes a lawyer; it is this process that, in the famous words of the fictitious Professor Kingsfield, allows a law student to "think like a lawyer." 53

Once a lawyer has found relevant law, 54 the lawyer must then interpret what the court has said about the law. And as all law students and lawyers know, this is not always as simple a process as it sounds. Many students come to law school ill-equipped to interpret the cases that are the building blocks of their legal education ${ }^{55}$ and much of their time in law school is spent acquiring and honing this vital skill.

But even after the lawyer has located and correctly interpreted the law, it must still be placed in an appropriate context. The problem can be readily appreciated by use of a hypothetical example. If we assume that a pro se litigant is pursuing a cause of action for negligent infliction of distress under Maryland law, we can conclude, based on Maryland's failure to recognize this theory, 56 that the defendant will prevail, at least on this count of the complaint. Yet the pro se

\footnotetext{
$51 \quad$ For a public librarian's view of the current state of public access to the law, see Melissa Barr, Democracy in the Dark: Public Access Restrictions from Westlaw and Lexis available at http://www.infotoday.com/searcher/jan03/barr.shtml (last visited August 1, 2006). 52 See, e.g., AMY E. SlOAN, BAsic Legal RESEARCH: TOOLS AND STRATEGIES (3d ed. 2006); Christina L. Kunz Et Al, The Process Of Legal Research (6th ed 2004); Roy M. Mersky \& Donald J. DunN, Fundamentals Of Legal Research (8th ed. 2002); LAurel CuRrie OATES \& AnNe EnQuist, Just Research (2005); Morris L. COHEN Et Al, How To Find The LAW (9th ed. 1989). This is just a short selection of the numerous legal research books on the market.

53 The Paper Chase; Pilot (CBS television broadcast September 7, 1978).

54 If the lawyer has used the West digesting process to find the cases, it might be better to say that the lawyer has found the cases West's editors think are relevant.

55 Books have been written to help teach law students the reading techniques they need in order to become better legal readers. See, e.g., RUTH A. MCKINNEY, READING LiKE A LAWYER (2005).

56 Hamilton v. Ford Motor Credit Co. 66 Md. App. 46, 502 A.2d 1057 (Md. Ct. Spec. App. 1986).
} 
plaintiff has found a more recent case in the same regional reporter ${ }^{57}$ as that containing Maryland cases, 58 and while the case is from Connecticut, it is more factually on-point than the Maryland case, and might therefore not understand why the court still rules in the defendant's favor on this cause of action. But a lawyer will recognize that the location of the case in the same reporter is mere coincidence and that the factual similarities and more recent date are irrelevant; what is controlling here is the jurisdiction, and the fact that Connecticut has recognized a cause of action will likely not affect a Maryland court's decision to dismiss the count in the complaint. ${ }^{59}$

This is not to say, of course, that many non-lawyers cannot use the law they find in as effective and persuasive a manner as many lawyers, or that lawyers are more intelligent than non-lawyers, but it is to say that the act of finding and using the law effectively are skills that define lawyers and that lawyers have been trained in these skills in law school and that many have spent considerable time refining these skills in practice.

Many courts have pro se clerks who seek to understand the legal theories behind allegations filed by pro se litigants, and law clerks and judges in courts without such a department often will perform the same function, seeking to translate a pro se pleading into a complaint with a cognizable legal theory. But a pro se litigant who files a document influenced by inappropriate case law might be deluded into describing a legal theory that fails to match the facts, and while a judge might give the litigant the benefit of doubt when trying to understand what theory might be relevant to the claim, the same judge will likely be less tolerant of an incorrectly-pled theory. In short, unmediated access to the law could lock a pro se litigant into an incorrect theory and make a judge less willing to correct the mistake. ${ }^{60}$

\footnotetext{
$57 \quad$ The Atlantic Reporter, Second Series.

58 Craig v. Driscoll, 64 Conn. App. 699, 781 A.2d 440 (Conn. App. Ct. 2001).

59 Such a result is not mandated, of course. The Maryland court might be looking for a test case to send to the Court of Appeals in order to effect a change in Maryland law, and a skilful advocate might be able to lay the groundwork for this change by reference to, among other things, the Connecticut case. But the more predictable result in such a case would be a dismissed count.

60 In an imperfect but useful analogy, the internet's unmediated "Wikipedia" site, available at http:/ / www.wikipedia.org/ (last visited July 26, 2006), contains articles that have the appearance of authority, even though they could be completely inaccurate. The open-access nature of the Wikipedia site means that anyone can post or edit an entry, and the sophisticated presentation software available as part of the site means that any entry, whether it be completely accurate or entirely fictitious, will look the same. Unwitting users of the site could be misled into following a theory supported by a Wikipedia entry that has no actual substance in reality. For this reason, many scholars mistrust anything that appears on the Wikipedia site and do not recognize it as a viable research source.
} 
But while there might be dangers associated with open access to the law, internet access ${ }^{61}$ does not substantially increase these dangers over those associated with the print-based access to the law available now. ${ }^{62}$ It is impossible to quantify the extent to which pro se litigants might be harmed by misunderstanding the law they read, just as it is impossible to quantify the extent to which they would be aided in formulating theories of which they might otherwise have been unaware except through their serendipitous discovery during the research process. And even if the potential harm to non-lawyers were to be increased by open internet access to the law, it would be extraordinarily dangerous to the fabric of a democratic society for lawyers to assume the role of legal gatekeepers, deciding who may, and may not, have access to court decisions.

Such a paternalistic approach might originate in the best of intentions but the possibility for abuse is readily apparent. It is surely better to acknowledge that open access to legal information is the hallmark of a democratic society ${ }^{63}$ and find ways in which such open access can be achieved in a digital age. And that discussion brings us first to a consideration of legal citation, how it has assumed the central role it now occupies in describing legal information, and what effect that role might have on the public's access to that information.

\section{A Short History Of American Legal Citation}

Lawyers might be tempted to think that the history of American legal citation begins in 1926 with the publication of the first edition of A Uniform System of

61 For one significant group of pro se litigants, it is unclear how much an internet-based legal information database would be helpful. Many prisoners are unable to access the internet, and are either dependent on out-of-date and under stocked print libraries, or else on a service, such as that marketed by Lexis, in which a CD-ROM of case law is uploaded into a kiosk specially designed for a prison environment. See, Amy Hale-Janeke, The "Inside" Information on New Jail Kiosks, LISP NeWSLETTER, June 2004. Available at

http://www.aallnet.org/sis/lisp/news2004_1.pdf (last visited May 19, 2006)(describing a joint venture between LexisNexis and Touch Sonic Technologies to provide legal information kiosks to several county jails in California and Hawaii). There is no reason, of course, why legal information from an open-access legal information database could not also be made available on CD-ROM for any potential user who was unable to access the information through the internet 62 Indeed, the hypothetical pro se litigant described supra, nn.56-59 and accompanying text, might be more confused by the location of the two found cases in the same regional reporter than would be the case were cases to be grouped instead by jurisdiction, thereby minimizing the possibility of confusion and emphasizing the importance of the jurisdiction as a source of authority.

63 "Since the founding of our nation, the cornerstone of information policy in the United States has been the principle of universal access to government information." Wayne P. Kelley, U.S. Superintendent of Documents. Wayne P. Kelley, Keeping Government Information Public, LiBR. J. May 15, 1998, at 34, quoted by Richard A. Danner, Dissemination of Legal Information: Social and Political Issues in the United States, available at

http://www.law.duke.edu/fac/danner/paper2.html (last visited July 24, 2006). 
Citation, ${ }^{64}$ now commonly known as "The Bluebook." But lawyers and judges had been referring to previous cases long before that, 65 and at least two citation systems predated the Uniform System. ${ }^{66}$ Since The Bluebook's ascendancy, two challengers have attempted to displace it as the preferred citation manual for American legal information, the University of Chicago's "Maroonbook" and the Association of Legal Writing Directors' "ALWD Manual."

\section{A. The Bluebook}

The Bluebook first appeared in $1926^{67}$ although at the time it was neither blue nor a book. ${ }^{68}$ Nor did it make any claims to being a definitive "system" of citation, noting that it "did not pretend to include a complete list of abbreviations or all the necessary data as to form" and that "each legal publication shall be free to cite its own name as it chooses." 69

64 A UNIFORM SYSTEM OF CitATION (1st ed. 1926), reprinted in THE BLUEBOOK: A SiXTY-FIVE YEAR RETROSPECTIVE (1998).

65 For an exhaustive study of the history of legal citation, see Byron D. Cooper, AngloAmerican Legal Citation: Historical Development And Library Implications, 75 LAW LIBR. J. 3 (1982).

66 Id. at 21; the Nebraska Supreme Court's Rules for Citations, 30 AM. L. Rev. 107 (1896), and the Judge Advocate General's office's 1919 manual, Ruppenthal, Methods Of Citing Statue Law, 12 LAW. LIBR. J. 1 (1919). In addition to these, the Yale Law Journal's Abbreviations and Form of Citation, a pamphlet dating from 1921, was a direct predecessor of Griswold's 1926 pamphlet. A reprint of the 1921 pamphlet, and its 1924 reprint, can be found as appendices to THE BLUEBOOK: A SiXTY-FIVE YEAR RETROSPECTIVE (1998).

67 James W. Paulsen, An Uninformed System Of Citation, 105 HARV. L. ReV. 1780, 1782 (1992)(book review). Nor was The Bluebook conceived in Massachusetts, but rather in Cleveland, Ohio, where its creator, Erwin Griswold - a Harvard law student at the time - was spending the summer. Id.

68 "The cover is not an authoritative blue, but a soothing olive, with undertones of gray." Id. It was not until the sixth edition, published in 1939, that the Bluebook first became blue. Byron D. Cooper, Anglo-American Legal Citation: Historical Development And Library Implications, 75 LAW Libr. J. 3 , 21(1982). And at twenty-six pages in length (Timothy D. Blevins, A Hallmark Of Professional Citation Form, 29 T.MARSHALL. L. REV. 89, 90, n.5 (2003)), the first edition hardly qualified as a book. In fact, the first sentence described the publication as a "pamphlet." Paulson, supra n.67, at 1782

$69 \quad I d$. 
Twenty-three years, five editions after its first publication, ${ }^{70}$ and after the Harvard Law Review editorial board had been joined as compiler by the law review editors of the University of Pennsylvania, and Yale and Columbia Universities, ${ }^{71}$ The Bluebook was adapted as the "unanimous choice for a proposed national system of citation" by the first national conference of law review editors. ${ }^{72}$ Yet this "national system" was still confined to the rarified world of law reviews, and it was only in 1976 that The Bluebook began to market itself as a citation system for courts and attorneys as well. ${ }^{73}$ Since then, however, The Bluebook has been the undeniable force in legal citation, taught to generations of lawyers as the method of citing to sources. It is the yardstick by which all other citation systems must be measured.

\section{B. The Maroonbook}

The Bluebook had the legal citation market essentially to itself ${ }^{74}$ until 1989 and the appearance of the University of Chicago's slim, maroon-colored challenger, inevitably known as the Maroonbook. ${ }^{75}$ This slim pamphlet, ${ }^{76}$ perhaps unconsciously, adopted a similar tone to that of Erwin Griswold' first Bluebook, noting that it contained a "set of guidelines" for citation, and that because it is neither possible nor desirable to write a particular rule for every sort of citation

\footnotetext{
70 Blevins, supra n.68, at 95, n.22. The second through sixteenth editions of The Bluebook were published in 1928, 1931, 1934, 1936, 1939, 1947, 1949, 1955, 1958, 1967, 1976, 1981, 1986, 1991, and 1996. A. Darby Dickerson, An Un-Uniform System of Citation: Surviving With The New Bluebook 26 STETSON L. REV. 53, 55 (1997). The seventeenth edition was published in 2000. Blevins, supra, n.68, at 95, n.22. And the eighteenth edition was published in 2005. A former executive editor of the Harvard Law Review has explained that new editions of The Bluebook appear "not when the revisionist spirit grips law review editors in Cambridge, New Haven, New York, and Philadelphia, but when revenues from Bluebook sales dip unacceptably." Chen, supra n.35, at 1527.

$71 \quad$ Paulsen, supra n. 67, at 1782.

$72 \quad$ Id.

$73 \quad$ Id., at 1783 .

74 The legal citation field is not quite as barren as The Bluebook's self-designation as "A Uniform System of Citation might lead one to believe. Some states publish their own style and citation manuals. See, e.g., Katherine D. LA Bock, et AL, NeW YORK LAW Reports StYle MANUAL (2002). And as every first year law student can attest, many to their chagrin, West employs its own citation format that is deceptively close to, but is emphatically not the same as, The Bluebook's format.

75 The University Of Chicago MANuAl Of Legal Citation (The University of Chicago Law Review et al. eds. 1989)(“The Maroonbook").

76 At 63 pages, including index, the first edition of The Maroonbook was more than twice the length of the original Bluebook, but was approximately one quarter the length of The Bluebook 14th edition's (the version in effect at the time of The Maroonbook's publication) 255 pages.
} 
problem that might arise, the rules leave a fair amount of discretion to practitioners, authors, and editors." 77

Whether The Maroonbook was created out of a genuine frustration with The Bluebook's highly formalist approach to legal citation ${ }^{78}$ or from a desire to make some money from the lucrative legal citation market and simultaneously to diminish the luster of Chicago's Ivy League rivals ${ }^{79}$ is unclear. What is certain is that The Maroonbook failed to reach whatever goals its creators set for it: hardly any law review uses The Maroonbook as a citation manual, and, at best, its citation precepts are taught only at its school of origin. ${ }^{80}$

The reasons for The Maroonbook's failure are difficult to parse. Coombs' prediction that the winner of the Bluebook/Maroonbook contest would be "the more efficient guide to legal citation . . ." 81 cannot be correct: were efficiency alone the arbiter of a citation format's success, The Maroonbook would surely have gained at least a more permanent place in the marketplace. Another criticism of The Maroonbook - that its freedom from strict citation rules requires too much attention to insignificant citation details ${ }^{82}$ - is also surely not the reason

77 The Maroonbook, supra n.75, at 7.

78 The stark contrast between The Bluebook's unabashedly formalist approach and the Harvard law school faculty's leading role in attacking legal formalism did not go unnoticed by at least one commentator. See, Mary Coombs, A (Sort Of) Review of the University of Chicago's Manual of Legal Citation, 76 VA. L. REV. 1099, 1104-05 (1990).

79 Coombs notes only that the Chicago students had decided "to compete, and thereby allow the market to decide which is the more efficient guide to legal citation...." Id. at 1103. A more aggressive strategy is hinted at by another commentator, who described Chicago's decision to "grab market share away from the Bluebook's monopoly." Christine Hurt, Network Effects and Legal Citation: How Antitrust Theory Predicts Who Will Build A Better Bluebook Mousetrap in the Age of Electronic Mice, 87 IOWA L. REV. 1257, 1277 (2002).

$80 \quad$ In 1997, Dickerson listed the Vanderbilt Law Review, the Berkeley Woman's Law Journal, and the Supreme Court Review as the only non-University of Chicago journals to have adopted The Maroonbook. Dickerson, supra n.54, at 93.

81 Coombs, supra n.78, at 1103.

82 Bryan A. Garner, An Uninformed System Of Citation: The Maroon Book Blues, 1 SCRIBES J. LEGAL WRITING 191, 194 (1990). In any case, Garner's concern is surely overstated. He uses, as examples, the question of whether he should use infra and supra, and whether he should italicize ex parte and de facto, noting that The Maroonbook "says merely that 'I need not.'" Id. Garner concludes that this is "precisely the problem with The Maroonbook. You must consciously consider what before had been the merest matter of form, too insignificant to require thought." Id. But Garner surely is not speaking for the vast majority of legal practitioners and authors, for whom a decision on whether or not to use infra or supra, or whether to italicize certain nonEnglish terms, would be take a fraction of a second. By contrast, leafing through The Bluebook to find the relevant information, then assimilating the rule encoded within The Bluebook's notoriously opaque writing style, could take substantially longer. The Maroonbook's avoidance of formality on such citation details seems unlikely to have been "precisely" the problem with The Maroonbook's acceptance by the legal academy and the practicing bar. It might, on the other hand, have been a problem for law students. Law school is place of almost existential doubt, a 
for The Maroonbook's failure; not enough people knew about The Maroonbook, or were forced to follow it, to participate in a counter-revolution against its liberated ways.

A more plausible explanation for the Maroonbook's failure to gain traction in the legal citation market is offered by Christine Hurt, who argues that it was the strangeness of the Maroonbook's approach - generating citations that looked like traditional citations erroneously written - that caused an insufficient number of legal writers to adopt the new system. ${ }^{83}$ It might also be true that the Maroonbook's publishers ${ }^{84}$ were insufficiently active in publicizing the Maroonbook's benefits, perhaps relying too much on the strength of a favorable article by Judge Richard Posner ${ }^{85}$ to generate publicity and a favorable reception for the book. Neither of these mistakes can be attributed to the next, and substantially more serious, challenger to The Bluebook's hegemony.

\section{The ALWD Manual}

The ALWD Manual was first published in $2000^{86}$ and, by its sheer heft alone, ${ }^{87}$ declared that it was taking a different path from The Maroonbook's minimalism.

world in which the Socratic teaching method replaces knowledge with questions and understanding with incomprehension. For many law students, The Bluebook is a binary state refuge in the dismal swamp of hypothetical ambiguity that can be law school classes, replacing doubt with rules, blurred doctrine with a sharp focus, and principles with rules. If The ALWD Manual provoked hostile reactions amongst first year students for offering limited citation freedom (see Pether, Discipline and Punish, supra n.2, at 129), the reaction to The Maroonbook would likely have been even more volatile. But even though I am not persuaded by Garner's analysis of the "precise" problem presented by The Maroonbook, another problem he identifies that free citation form might hinder a researcher's ability to find a case using the very literal interface of computer-assisted legal research databases - although likely also not the reason for The Maroonbook's marginalization within the legal citation market, is nonetheless a perceptive and important point to which we shall return later.

83 Hurt, supra n.63, at 1280-81. Hurt's description of the Maroonbook's failure to generate citations that are "interoperable" with The Bluebook is particularly interesting.

84 The Maroonbook was published by The Lawyer's Co-Operative Publishing Company, Bancroft-Whitney Company, and Mead Data Central, Inc.

85 Richard Posner, supra n.40.

86 ALWD Manual, supra n.20.

87 The first edition of the ALWD Manual was 470 pages long, including index. Id. The most recent third edition is 572 pages long. ALWD CiTATION MANUAL: A PROFESSIONAL SYSTEM OF CITATION (Darby Dickerson, ed. 3d ed. 2006). Thus, the present edition of the ALWD Manual is more than 150 pages longer than the 415 page 18th edition of The Bluebook. A least part of this disparity in length can be attributed to the ALWD Manual's presentation style. The Preface to the ALWD Manual's third edition notes that "[e]very effort has gone into writing and printing the book in a format that is accessible as well as gentle on the eye." Preface at xxiii. The result of these efforts is a book that is as readable as a citation manual could be, although the readability is achieved at the expense of increased size. 
The ALWD Manual is, in intent, a "restatement of citation," 88 and by presenting essentially the same citation formats as those in The Bluebook, 89 the ALWD Manual's editions are making the rhetorical statement that legal citation format does not "belong" to The Bluebook. ${ }^{90}$

Whether by coincidence or design, the similarity between case and statutory citations generated using the ALWD Manual and The Bluebook means that ALWD Manual citations are largely "interoperable" using Christine Hurt's term, thereby avoiding one of The Maroonbook's significant drawbacks. And the fact that the people who decide what citation system will be taught in the first year of law school were the very legal writing directors who make up ALWD's membership, ${ }^{91}$ combined with the support of a large commercial publisher, ${ }^{92}$

\footnotetext{
88 Lysaght \& Tonner, supra n.16

89 There are, of course, superficial differences between the two citation formats presented by the ALWD Manual and The Bluebook, as a detailed point-by-point comparison would disclose. But unlike The Maroonbook, for the most commonly used case and statutory materials, the citation styles of the ALWD Manual and The Bluebook are sufficiently similar for the differences to escape anything but detailed scrutiny.

90 Christine Hurt notes that citation is a "creature of common law" not statute, which is, perhaps, a more elegant way of describing the ALWD Manual's purpose and effect. Christine Hurt, supra n.79, at 1282. The editors of the Harvard Law Review had earlier noted The Maroonbook's tendency, when it gave something akin to a citation rule, to be "strongly influenced by the Bluebook's [rule]. Even when they expressly reject a Bluebook rule, they retain much of the Bluebook's organizational scheme." Book Note, Manual Labor, Chicago Style 101 HARV. L. REV. 1323, 1330 (1988). In a deft example of sleight-of-hand, the anonymous author (The Bluebook's rules had not yet changed to allow the author's name to be included in a citation) deflects a recognition of the fact that most of the "rules" articulated in The Bluebook are not proprietorial by commenting that "the Chicago stylists can sleep well, at night or in class, knowing that any allegations of copyright infringement can be met by the parody defense." Id. Notwithstanding the author's implied assertion the citation rules are sufficiently the property of The Bluebook's editors to be copyrightable, a failure to prosecute a copyright infringement claim against the editors of The Maroonbook or the ALWD Manual might seem to be at least a tacit admission that citation format is something that lies firmly in the public domain.

91 In the interests of full disclosure, I am a member of ALWD, although the law school where I am the director of the legal research and writing program still uses The Bluebook as its citation manual.

92 The ALWD Manual is published by Aspen Publishers, a company owned by Wolters Kluwer. Aspen is a leading publisher of legal textbooks, making it in some ways the perfect publisher for the ALWD Manual. On the other hand, a disturbing pattern of new editions is emerging; the ALWD Manual is now in its third edition after only six years on the market. Since one of the triggers for the ALWD Manual's creation was the seeming instability and inconsistency of The Bluebook's approach to some elements of citation (see Lysaght \& Tonner, supra n.16, at 1058), it would be reasonable and correct to assume that the ALWD Manual's approach to citation has not changed significantly since 2000. And, indeed, "clarifications, updates, and additions" to the ALWD Manual are available on ALWD's website (ALWD Manual at 7), meaning that new editions are not necessary in order to correct minor errors or make appropriate adjustments in citations. A cynical observer might wonder, therefore, if the frequency of new editions of the ALWD Manual has more to do with the same financial
} 
means that the ALWD Manual made substantial and rapid inroads into the citation market. 93

But while the interoperability of the ALWD Manual's citation format might have contributed to its commercial success, it only serves to reinforce the importance of citation orthodoxy to American law students. One lesson that can be drawn from the failure of the defiantly heterodox Maroonbook, and the relative success of the more orthodox ALWD Manual is that American legal culture is very conservative when it comes to the appearance of citations; while innovation is welcomed when it comes to presenting citation principles, ${ }^{94}$ the citations themselves should look as they have always looked.

This means that both principal citation systems taught in American law schools reaffirm the primacy of case reporters published by the West Company. ${ }^{95}$ And therein lies, what I will argue, is a fatal flaw in our bibliographical practice that has the unintended consequence of restricting free and open access to the law.

\section{West's Role In The Legal Information Market}

West is not the only publisher of case law in the United States, but it is by far the most significant. It is the only comprehensive paper publisher of federal case law below the Supreme Court level ${ }^{96}$ and is the only publisher of state cases for

incentives that Jim Chen alleges are the basis for The Bluebook's new editions (see, Chen, supra n.35) than with significant changes in citation format.

93 Lysaght and Tonner noted that in August of 2000, the start of the first full academic year in which the ALWD Manual was available, "more than 80 United States law schools had adapted the ALWD ... Manual." Lysaght \& Tonner, supra n.16 at 1059. The ALWD Manual has not significantly expanded on this initial success; the ALWD website shows that, in 2006, 91 law schools use the ALWD Manual, exclusively or in combination with The Bluebook, to teach legal citation. Association of Legal Writing Directors' website, available at http:/ / www.alwd.org (last visited July 13, 2006).

94 The new (at the time of writing) 18th edition of The Bluebook certainly reflects some of the lessons the editors have learned from the ALWD Manual; sample citations are set apart from the instructional text by more white space, bracketed explanations of the parts of citations are included, and the text for those is in a different color, spaces are more clearly marked, and a new "bluepages" introduction to basic legal citation summarizes the most important citation principles.

95 Although West was acquired by Thomson in 1996, and is now properly called West, a Thomson Company, for purposes of convenience I will continue to refer to it as "West" here. 96 While the Supreme Court itself publishes the United States Reports, West publishes the Supreme Court Reporter and the Lawyer's Co-Operative publishes the United States Supreme Court Reports, Lawyer's Edition. The American Law Reports, Federal series also publishes selected federal decisions, using them as the basis for its annotations of doctrinal issues, but this series is published by the Lawyers Co-Operative, which is owned by West. Other than these, West directly publishes all other federal decisions: Courts of Appeals decisions appear in the Federal Reporter (for published decisions) and in the Federal Appendix (for selected unpublished 
twenty two states and the District of Columbia. ${ }^{97}$ West also publishes the decisions from the remaining twenty eight states as part of its National Reporter system. And even where West is not the exclusive publisher of state or federal court decisions, its copyrighted "key number" finding tool makes it the preeminent provider of legal information. ${ }^{98}$

West's digesting sets, in which cases are analyzed and synopsized according to a predetermined set of doctrinal divisions, first appeared in 1897,99 and gave West an unbeatable head start as a legal research resource. ${ }^{100}$ Indeed, it was not until 1973, and the introduction of the LEXIS database (later known as LexisNexis), 101 that West faced a serious challenge to its market position. ${ }^{102}$ In contrast to the pre-indexed approach employed by the West digesting system, ${ }^{103}$ LEXIS offered

decisions from 2001); selected Federal District Court decisions appear in the Federal Supplement series (from 1932), and the Federal Reporter (from 1880 to 1932), the Federal Rules Decisions (from 1938), or the Bankruptcy Reporter (from 1979); and selected Bankruptcy Court decisions appear in the Bankruptcy Reporter. All these opinions, and more unpublished decisions, can also be found on West's proprietary Westlaw database. Thus even though it appears that the printed materials offer at least some choice from West-published materials, that appearance is chimerical; only the Supreme Court's own U.S. Reports and the Lawyer's Edition of the United States Reports (which was owned by West until named as part of the divestiture mandated as part of the consent decree associated with Thomson's acquisition of West in 1996. KENDALL F. SVENGALIS, LEGAL INFORMATION BUYER'S GUIDE \& REFERENCE MANUAL 9 (2005)) are published by an entity not under West's direct control.

97 Alabama, Alaska, Colorado, Delaware, the District of Columbia, Florida, Hawaii, Indiana, Iowa, Kentucky, Louisiana, Maine, Minnesota, Mississippi, Missouri, North Dakota, Oklahoma, Rhode Island, South Dakota, Tennessee, Texas, Utah, and Wyoming.

98 As one yardstick of West's place in the legal information market, the "legal and regulatory" branch of the Thomson Corporation made $\$ 3.3$ billion in 2004, compared to the $\$ 1.7$ billion (approximately) made by LexisNexis in the same year. Ian Gallacher, Forty-Two, supra, n.45, at 175, n.115 (and other sources cited therein).

$99 \quad$ Lynn Foster \& Bruce Kennedy, The Evolution of Research: Technological Developments in Legal Research, 2 J. APP. \& PROCESS 275, 276 (2000).

100 West's principal competition at the time was the Annotated Reports, first published in 1871. Frederick C. HicKS, MATERIALS AND Methods OF Legal ReSEARCH 144-45 (3d ed. 1942). The Annotated Reports approach, in which a leading case is used to anchor an annotated discussion of a specific legal topic, is still familiar to lawyers today as the American Law Reports, or A.L.R., the name adopted by the Annotated Reports in 1919. But while A.L.R. annotations can often be a fruitful departing point for legal research, only a courageous, or foolhardy, lawyer would begin and end the research of an issue with them without cross-checking the results of such research with a search of more traditional West-published materials.

101 For a description of the genesis and development of the LEXIS database, see William G. Harrington, A Brief History of Computer-Assisted Legal Research, 77 LAW LIBR. J. 543 (1984-85). 102 West responded to this challenge with its introduction of the Westlaw database in 1975. Id. at 553 .

103 For a brief discussion of the benefits and problems associated with pre-indexed legal research, see, Ian Gallacher, Forty-Two, supra, n.45, at 179-82. 
a free-form search protocol based on Boolean logic. ${ }^{104}$ Yet even the LexisNexis service relies on page number information obtained from West, ${ }^{105}$ a practice appropriately described as a "tax for the use of the law, preventing effective price competition ...." 106

\section{West has fought zealously to protect its guardianship of legal information. ${ }^{107}$ Recognizing that copyright protection for the decisions themselves is impossible, 108 it has nonetheless sought copyright protection for the pagination in its reporters, ${ }^{109}$ something that goes directly to the heart of the purpose of a}

104 The process of Boolean searching in LexisNexis and Westlaw, whereby the researcher selects key terms and searches for them within relational parameters also selected by the researcher is familiar to all lawyers and law students. Both LexisNexis and Westlaw have also introduced "natural language" search engines that do not require the researcher to determine the relational context of the key terms. In fact, however, these "natural language" engines identify key words and concepts within the text entered by the researcher and translate those terms into a Boolean search. See, Marilyn Walter, Retaking Control of Teaching Research, 43 J. LEGAL EDUC. 569, n.1 (1993). Computer-Assisted legal research solves some of the problems of pre-indexed searching, but creates some problems of its own. For a brief discussion of the issues associated with computer-assisted legal research, see, Ian Gallacher, Forty-Two, supra, n.45, at 183-90. Perhaps in response to the problems identified with the freer form of research associated with computer-assisted legal research, both Westlaw and LexisNexis now both offer the alternative of performing pre-indexed searches in addition to Boolean and "natural language" based searches. 105 See Deborah Tussey, Owning the Law: Intellectual Property Rights in Primary Law, 9 Fordham INTELL. Prop. MEDIA \& ENT. L. J. 173, 186 n.31 (1998), citing Thomas Scheffey, Raiders of the West Ark, CONN. LAW TribunE, Aug. 12, 1996, at 1 (claiming that the license fee for Lexis' use of West page numbers negotiated after litigation between the two publishers was $\$ 10$ million.) 106 Vito Petretti (Note), Matthew Bender \& Co. v. West Publishing Co.: The End of West's Legal Publishing Empire?, 43 VILL. L. REV. 873, 911 n.211 (1998).

107 As, indeed, it must do. Thomson, West's corporate owner, is a publicly-traded corporation and has a responsibility to its shareholders to protect its assets from dilution. So while I am critical of the decisions that have allowed West to attain its present state of preeminence in the American legal publishing market, and while I will argue here that West's role in publishing American law is anti-democratic and serves to constrict access to the law, I do not intend by such criticism to demonize West, or any of the other commercial legal information publishers, for the decisions they are obligated, as for-profit corporations, to take in their own defense. Nor is any criticism in this article directed at the work West and other legal information publishers have done to disseminate the law. West in particular has published its comprehensive and sophisticated digesting system for over one hundred years, making the law more accessible in this country than in most others, and Westlaw and LexisNexis are fast and impressive databases constantly on the cutting age of information technology. Nonetheless, the nature of a capitalist system, and the power West has to control legal information, means that some less-than-desirable results will flow from West's position, and it is those results that are properly the subject of this article.

108 This issue, at least, is well-settled. The Supreme Court's decision in Wheaton v. Peters, 33 U.S. (8 Pet.) 591 (1834), makes clear that no reporter could copyright the court's written opinions. $I d$. at 668 . The Court later expanded its decision to include state court opinions as well. Banks v. Manchester, 128 U.S. 244 (1888).

109 West pursued, and obtained, a preliminary injunction, later affirmed by the Eighth Circuit, barring Lexis' publisher from using West pagination in Lexis versions of cases. West 
citation. ${ }^{110}$ West also successfully intervened in litigation seeking to release the JURIS database, ${ }^{111}$ thereby helping to keep the information stored in that database private and unavailable to the general public. ${ }^{112}$

Publishing Co. v. Mead Data Central, Inc., 799 F.2d 1219 (8th Cir. 1986). The Eighth Circuit found that, under certain circumstances, pagination could be copyrightable, (id. at 1223-26), and that the West's labor in generating its reporters was sufficient to meet the standard required for copyright protection. Id. at 1227. Despite some uncertainty over the validity of the Eighth Circuit's decision in light of a subsequent Supreme Court decision, Feist Publications, Inc. v. Rural Telephone Service Co., 499 U.S. 340 (1991), a United States District Court for the District of Minnesota reaffirmed the Mead decision's vitality in another dispute over a publisher attempting to use West's page numbers in a competing compilation of cases. Oasis Publishing Co., Inc. v. West Publishing Co., 924 F.Supp. 918 (D.Minn). The Court held that Feist did not overrule Mead, (id. at 923), and that West's labor was sufficiently creative to merit copyright protection even in Feist had articulated a new test. Id. at 924. Oasis appealed the district court's ruling and West, in a move suggesting that it was not too confident about the viability of the decision, decided to settle the case. Peretti, supra n.91, at 897, n.118. A third decision on the copyrightability of West's page numbers was not as successful for West. In Matthew Bender \& Co. v. West Publishing Co., 158 F.3d 674 (2d Cir. 1998), cert. den. sub nom West Publishing Co. v. HyperLaw Inc., 526 U.S. 1154 (1999), the Second Circuit affirmed a lower court ruling that West's page numbers were not protected by copyright. Id. at 689 .

110 A case citation without a page number would, of course, be meaningless. And even West appears to agree that citation to the first page of a decision is a "fair use" for purposes of the Copyright Act of 1976. Petretti, supra n.106, at 892. Even with a first page designation, however, the absence of pinpoint page citations, giving the actual page in the decision on which the cited material appears, would violate the first of Paul Axel-Lute's principles of citation form: "A citation should contain sufficient information to identify unambiguously the material cited." Axel-Lute, supra n.1, at 148. Any citation without pinpoint page information would not be unambiguous, requiring the reader to read carefully through often lengthy opinions in order to find the cited language or proposition, leading to potential confusion where a point had been paraphrased instead of directly quoted. And judges notice when pinpoint page information is missing. In a survey of the judges on three federal circuits (the First, Second, and Tenth Circuit Courts of Appeals), David Lewis recorded the judges' responses to a series of questions. David Lewis, If You Have See One Circuit, Have You Seen Them All? A Comparison Of The Advocacy Preferences Of Three Federal Circuit Courts Of Appeal [sic], 83 DenV. L. Rev. 893 (2006). Although Lewis' method of presenting the data provided by the judges is relatively imprecise (Lewis displays each question with a bar graph recording, for each circuit, whether the judges strongly agreed with the statement, showed no preference, or strongly disagreed. The shorter the graph, the more the judges strongly agreed. But there is no scalar calibration, leaving the reader unclear as to truly how strong the agreement or disagreement was), the results indicate that the judges in each circuit, although to a different degree, all strongly agree with the proposition that "[c]ase citations should almost always include a specific page reference" Id., at 914. And judges in the Second and Tenth Circuits agreed (with the judges in the Tenth Circuit agreeing more strongly than those in the Second) that "I am suspicious about whether the authority stands for the proposition asserted when a case citation lacks a specific page reference." Id. The judges of the First Circuit displayed no preference in response to this question. Id.

111 Not to be confused with "Juris", the registered trademark of a firm that provides business and management software principally for mid-sized law firms. Available at http:/ / www.juris.net (last visited July 11, 2006), or "Jurist," a legal news and information site maintained by the law faculty and students at the University of Pittsburgh and available at http:/ / jurist.law.pitt.edu (last visited July 11, 2006). 


\title{
V. The Failure Of Alternatives To Market-Based Legal Information
}

\author{
Despite West's attempts to control as much of the law as possible, alternatives to \\ West-published materials do exist. Indeed, in this internet age, federal courts, at \\ least, are required to make their written opinions available to the public. ${ }^{113}$
}

112 The JURIS affair is a depressing tale of opportunities lost. JURIS (the acronym stands for "Justice Retrieval and Inquiry System") was created in 1971 by the Department of Justice ("DOJ"), building on an electronic collection called FLITE (another federal governmental acronym, this time standing for "Finding Legal Information Through Electronics") developed by, of all people, the U.S. Air Force in 1963. James H. Wyman, (Comment) Freeing The Law: Case Reporter Copyright And the Universal Citation System, 24 FLA. ST. U. L. ReV. 217, 254 (1996). The FLITE database contained a collection of Supreme Court opinions, and formed the basis of the JURIS database. Wyman, supra at 254. Over time, JURIS developed into collection of federal case law, and included a citator function that allowed DOJ attorneys, and other federal and state government lawyers whose agencies entered into an agreement with the DOJ to allow them to use the service, to confirm that cases were still good law. Id. The DOJ entered into a contract with West in 1983, pursuant to which West performed data entry and database management services for ten years. Id. Incredibly, the contract permitted West to remove all information input by it into the system should it ever decide to terminate its relationship with the DOJ, something it did in 1993 after a non-governmental "information activist" filed a petition to gain public access to JURIS. Id. West's decision essentially crippled JURIS as an ongoing tool for government lawyers, but the DOJ did not erase the remaining data and JURIS could still have been used as the basis for a public-access legal information system. Accordingly, a nonprofit group brought a Freedom of Information Act ("FOIA") request to make the JURIS database available to the public. Tax Analysis v. Department of Justice, 913 F.Supp. 599 (D.D.C. 1996). West intervened in the action because of its "substantial interest" in the JURIS database (id. at 601), and the district court granted its motion to dismiss, as well as the DOJ's partial motion to dismiss, finding that JURIS was not an "agency record" within the contemplation of FOIA. Id. The JURIS database has never seen the light of day, although in an ironic development, FLITE, its predecessor, is now available both from the Government Printing Office, available at http://www.access.gpo.gov/su_docs/supcrt/index.html (last visited July 11, 2006) and from the Department of Commerce, available at http:/ / www.fedworld.gov/supcourt (last visited July 11, 2006). The FLITE database contains 7,407 Supreme Court decisions from 1937 to 1975 and this limited number of cases, together with a rudimentary (at best) search engine, renders it no more than a historical curiosity.

113 The E-Government Act of 2002, Pub. L. No. 107-347 (codified at 44 U.S.C. § 3501 Sec. 205(a) provides that " $[t]$ he Chief Justice of the United States, the chief judge of each circuit and district and of the Court of Federal Claims, and the chief bankruptcy judge of each district shall cause to be established and maintained, for the court of which the judge is chief justice or judge, a website that contains the following information or links to websites with the following information:

(1) Location and contact information for the courthouse, including the telephone numbers and contact names for the clerk's office and justices' or judges' chambers.

(2) Local rules and standing or general orders of the court.

(3) Individual rules, if in existence, of each justice or judge in that court.

(4) Access to docket information for each case.

(5) Access to the substance of all written opinions issued by the court, regardless of whether such opinions are to be published in the official court reporter, in a text searchable format." The requirement of Sec. 205(a)(5) is particularly interesting, since the "official" status of all West federal reporters is unclear, at best. The Bluebook requires citation to United States Reports for 
Well-intentioned though this requirement is, however, it has failed to produce a satisfactory method of delivering usable and findable legal information.

Although federal courts have "enthusiastically embraced e-filing" of litigation documents, and have "far exceeded the requirements of the E-Government Act" in this regard, ${ }^{114}$ the courts have been less enthusiastic about disseminating their opinions using the internet. Even though they have received a favorable ruling from the Judicial Conference on the meaning of the term "written opinion," 115 thereby allowing them to say what is and is not a written opinion, nineteen of the nearly two hundred federal courts reported that they were "deferring compliance with the Act's requirements as to the accessibility of written opinions in some respect." 116

And even those courts that have made their "written opinions" available to the public pursuant to the E-Government Act's requirement are not, it would appear, in full compliance with the letter or spirit of the Act. While some court websites contain full-text search capabilities, ${ }^{117}$ others do not. ${ }^{118}$ And some courts ${ }^{119}$ use PACER $^{120}$ as their means of making opinions public.

\footnotetext{
Supreme Court cases, allowing citation to the Supreme Court Reporter or United States Supreme Court Reports, Lawyers' Edition only if a case is not yet published in the United States Reports. The Bluebook, Table T.1, at 193. The Bluebook requires citation to the Federal Reporter for Courts of Appeals cases and to the Federal Supplement, Federal Rules Decisions, or Bankruptcy Reporter if District Court cases are published therein. Id. at 194-95. The ALWD Manual, however, lists all federal reporters but the United States Reports as "unofficial." The ALWD Manual, Appx. 1, at 404-05.

$114 \quad$ John C. Reitz, E-Government, 54 Am J. ComP. L. 733, 739 (2006).

115 The Judicial Conference has defined the E-Government Act's use of "written opinion" as meaning "any document issued by a judge or judges of the court, sitting in that capacity that sets forth a reasoned explanation for a court's decision," but the Judicial Conference also notes that "[i]n the courts of appeals, only those documents designated as opinions of the court meet the definition of 'written opinion.'" Memorandum on Compliance with Website Requirements of the E-Government Act to All Chief Judges, United States Courts, from Leonidas Ralph Mecham 2 (Nov. 10, 2004), quoted by, Stephen B. Burbank, Judicial Accountability to the Past, Present And Future: Precedent, Politics and Power, 28 U. ARK. LitTle Rock L. ReV. 19, 24 (2005).

116 Burbank, supra, n.115, at 24.

117 The Fourth Circuit's website, available at http:/ / www.ca4.uscourts.gov/ (last visited July 12 , 2006), has a relatively easy-to-use full-text search feature with menu options provided for the most common Boolean operators.

118 The Tenth Circuit's website, available at http:/ / www.ca10.uscourts.gov/ (last visited July 12, 2006), has the court's opinions since 1995, but only in archived form, accessible by docket number. Although there is a "search" box on the website, there are no apparent instructions on how court opinions might be searched for specific terms occurring in the text.

119 For example, the United States District Court for the Eastern District of Virginia. Available at http://www.vaed.uscourts.gov/opinions/index.htm (last visited July 12, 2006).

$120 \quad$ PACER stands for "Public Access to Court Electronic Records."

http:/ / www.vaed.uscourts.gov/opinions/index.htm (last visited July 12, 2006).
} 
Viewed as a public information source, PACER must be considered a dismal failure. A researcher seeking to find, for example, an opinion written by a specific judge is told that opinions can be viewed without charge, but is also warned that "viewing case docket sheets and other records through PACER costs 8 cents per page (with a maximum charge of $\$ 2.40$ per document.") ${ }^{121}$

The researcher intrepid enough to continue with accessing court opinions through PACER is then directed to the PACER registration page, ${ }^{122}$ only to learn that, while there is no registration fee, "the Judicial Conference of the United States has established a fee to be collected for access to PACER. All registered agencies or individuals will be charged a user fee. Access to web based PACER systems will generate a $\$ .08 \ldots$ per page charge." 123 This seems to contradict the previous information about being able to view opinions without charge, and a visit to the "frequently asked questions" area of the website is uninstructive. ${ }^{124}$

The impression that the researcher might be charged for viewing court opinions is strengthened by the on-line registration process. ${ }^{125}$ After being asked for credit card information, ${ }^{126}$ the researcher must click a box indicating that PACER's policies and procedures have been read and understood. ${ }^{127}$ Only once this entire process has been agreed to, and the password and login procedures

\footnotetext{
$121 \quad I d$

122 Available at http:/ / pacer.psc.uscourts.gov/register.html (last visited July 12, 2006).

$123 \quad$ Id.

124 Available at http:/ / pacer.psc.uscourts.gov/cmecf/ecffaq.html\#GE55 (last visited July 12, 2006). The "frequently asked questions" relate to the use of PACER's CM/ECF ("Case Management/Electronic Case Filing" facility.

125 The online registration form can be accessed at https:// pacer.psc.uscourts.gov/psco/cgibin/regform.pl (last visited July 12, 2006).

126 Credit card information is optional, and a credit card is not required to access PACER, although a potential researcher must provide credit card information in order to receive a password to use PACER the same day as the form is submitted. Id. If the researcher chooses not to provide credit card information, the password and access information will be mailed out, and should be received by the researcher within a week. Id. The problem here, of course, is that a researcher must have either a credit card or a home address to access court opinions, thereby, at one stroke, excluding the homeless, who could access court opinions from court-maintained websites through internet access in public libraries but who will almost certainly be unable to use PACER. For this reason alone, PACER is an inadequate response to the open-access mandate of the E-Government Act.

${ }_{127} I d$. One of those policies and procedures provides that " $[t]$ he per-page charge applies to the number of pages that results from any search, regardless of the number of pages viewed, printed, or downloaded. Searches that result in no matches incur a charge for one page of data." Id. The researcher is being asked to sign what amounts to a blank check by agreeing to pay for the number of pages contained in a document without knowing, before access, how many pages the document has. For a researcher who still believes that there might be a charge for court opinions viewed on PACER, and aware that some court opinions can be quite lengthy, this might be a significant impediment to proceeding.
} 
have been received, will the researcher find confirmation that PACER will assess no fee for viewing court opinions. ${ }^{128}$

The rhetorical roadblocks to using PACER as a means of retrieving court opinions are not over even once the potential researcher has registered and received password and login information. The researcher must then go to the appropriate court's PACER login page, ${ }^{129}$ only to find the warning that "[t]his is a Restricted Web Site for Official Court Business only. Unauthorized entry is prohibited and subject to prosecution under Title 18 of the U.S. Code. All activities and access attempts are logged." 130 And the researcher navigates through this thicket of stern warnings and misleading information only to discover that cases on PACER are not truly full text searchable, as required by the E-Government Act.

In the absence of any meaningful full text searching capability, not to mention the absence of any searchable digesting or headnote annotations, PACER and court websites are entirely inadequate research sources ${ }^{131}$ but that, for present purposes at least, is not the problem. Even if one finds an opinion that is relevant to an issue one wants to include in a court filing, there is no way to cite to it in compliance with The Bluebook.

As an example, Judge Leonie Brinkema, of the United States District Court for the Eastern District of Virginia, wrote a decision in a case styled NBC Universal, Inc. v. NBCUNIVERSAL.COM, ${ }^{132}$ which can be found by scrolling through the Eastern District's 2005 cases on its PACER site. But when one opens up the window for that case, one sees a PDF version of the judge's slip opinion, exactly as it would be received by the parties in that case. Both The Bluebook ${ }^{133}$ and the

128 Unfortunately, I cannot provide a citation for the PACER web pages beyond the log-in screen, since these pages are password protected. As proof of my claim that court opinions are free for viewing on PACER, once all the seemingly contradictory prefaratory language has been ignored, I can only offer the fact that I viewed an opinion using PACER on May 14, 2006 and have not, to date, seen a charge for that access on my credit card bills.

129 The Eastern District of Virginia's login page can be accessed at https:/ / ecf.vaed.uscourts.gov/cgi-bin/login.pl (last visited July 12, 2006).

${ }_{130} \quad I d$ (emphasis in original).

131 And to be fair to the websites and PACER, they are not intended to be research sites, nor does the E-Government Act specify that they should be, although full-text searching is required and, as the Fourth Circuit's website demonstrates, is relatively easy to include.

132 For reasons that will shortly become clear, I will not provide further citation information for the case here, but rather infra, at n.133 and n.136.

$133 \quad$ Rule 10.8.1(b). "When a case is unreported but available in a separately printed slip opinion, give the docket number, the court, and the full date of the most recent disposition of the case." Under this rule, the citation for Judge Brinkema's decision would be NBC Universal, Inc v. NBCUNIVERSAL.COM, No.1:05cv268, E.D.Va. July 14, 2005). 
ALWD Manual 134 provide citation options, but only if the opinion is unreported. 135 Yet nothing on the opinion as reproduced on PACER makes it possible for a researcher to tell if the opinion has been published or not. Thus, in order to determine whether or not the opinion has been reported, a researcher must use conventional legal research tools to attempt to locate the case in a reporter. In essence, one must research anew the opinion one has already researched in order to be able to cite to it. 136

And therein lies the problem at the heart of the relationship between legal research and legal citation; if a researcher must conduct two separate searches to find usable citations for cases to support a legal proposition - one search on a public access site to find the case and one using conventional legal research tools to find the case's citation - then the researcher has saved no time or money by using the public access site. ${ }^{137}$ And if there is no justification for using a public access legal information site, except to waste time, energy, and money, it is unlikely that such sites will prosper.

$134 \quad$ Rule 12.18(a). "When a case is unreported and is available only in a separately paginated slip opinion, include the following components: Case name, $\bullet$ Docket number $\bullet$ (Court abbreviation •Exact date of disposition)." The ALWD citation for Judge Brinkema's decision would be indistinguishable from that generated under The Bluebook's rule 10.8.1(b).

135 Here, perhaps, is the solution to the question of why West should go to the trouble and expense of developing a reporter series devoted to the publication of unpublished decisions, a move described as "the crowning irony" of the legal publishing market. F. Allan Hanson, From Key Numbers to Keywords: How Automation Has Transformed the Law, 94 LAW LiBR. J. 563, 580 (2002). West's "startling" decision (Stephen R. Barnett, From Anastasoff to Hart to West's Federal Appendix: The Ground Shifts Under No-Citation Rules, 4 J. APP. PRAC. \& PROCESS 1, 2 (2002)), would, indeed, have made no sense in a world in which practitioners were not permitted to cite to a court's unpublished decisions when making arguments to that court. After the Eighth Circuit's decision in Anastasoff v. United States, 223 F.3d 898 (8th Cir. 2000), however, the pressure to permit citation to these unpublished decisions began to build. It is not fanciful to think that West, foreseeing the possibility that citation to unpublished decisions might be permitted in the near future, decided to produce a reporter dedicated to these decisions, thereby providing them with a viable citation format, something it did with the publication of the Federal Appendix the year after the Anastasoff decision was handed down.. Certainly this has been the result of West's decision to publish the Federal Appendix; both The Bluebook (at 193, table T.1) and the ALWD Manual (at 404, Appx. 1) list the Federal Appendix as a viable source for citation, whereas neither Westlaw nor LexisNexis appear in the tables (although, of course, citation formats for these sources do appear in both citation manuals). Accordingly, the Federal Appendix provides an "interoperable" citation format for unpublished decision and West has, in effect, gained control over unpublished decisions. Whether or not this was West's intention, this result is one of the clearest examples of the power citation has over legal information.

136 In fact, Judge Brinkema's decision is published, and therefore should be cited, according to The Bluebook rule 10 and ALWD Manual rule 12, as NBC Universal, Inc. v. NBCUNIVERSAL.COM, 378 F.Supp. 2d 715 (E.D. Va. 2005).

137 For a discussion of the financial issues surrounding the time involved in conducting legal research, see Gallacher, supra n. 45, at 197-201. 
Although I have used PACER here to illustrate the issue, the problems associated with the citation of cases bedevil other non-commercial legal information sites as well. Unless such sites can guarantee full historical coverage of all court opinions, allowing queries of multiple databases using one search string, with accurate and recognized citation information that allows the researcher to rely on that resource alone, and to generate a citation to the found information that will be accepted by all audiences, there is little if any reason for a legal researcher to use the site. And since lawyers are the logical target users of legal information sites, a failure to attract them in sufficient numbers to make the site commercially viable dooms the site to failure or, at best, a marginal existence, and more likely prevents the site from starting-up in the first place.

This issue has been of only theoretical significance until recently. The high cost of publishing the law in competition with West meant that, as a practical matter, West had no competitors during the heyday of print-based legal information. But the advent of computers, and more specifically the internet's world wide web, 138 combined with the dramatic drop in expense for scanning and storage of digital information makes alternative legal information publication technically and economically feasible. ${ }^{139}$

Even though the development of a commercial web site publishing American case law might be legally and economically feasible, and even were a developer to solve the not inconsiderable problems associated with such a site, ${ }^{140}$ the developer would still face some substantial hurdles. Not the least of these would be a possible legal battle with West, ${ }^{141}$ particularly if the developer chose to

138 It is hard to imagine, but the world wide web has only been a feature of life for twelve years at the time of writing. TIM BERNERs-LeE, WEAVING THE WeB: THE ORIGINAL DESIGN AND UltimAte Destiny OF THE WORLD WIDE Web By ITS INVENTOR 99 (1999). Although selecting a date on which the world wide web became a part of everyday life is a purely arbitrary act, I have selected December 15, 1994 because on that day Netscape released free over the internet Navigator 1.0, a web browser compatible with the three main operating systems then in effect (Microsoft Windows, Unix, and Macintosh). Id. "Within several months the majority of people on the Web were using it." Id.

139 The question of whether the scanning of cases published in a West-published reporter is a violation of copyright has been answered, in the Second Circuit at least, in the negative. Mathew Bender \& Co v. West Publishing Co., 158 F.3d 674 (1998). In the Bender case, HyperLaw sought to scan "the title, texts, and certain other information directly from the West reports." Mathew Bender \& Co., Inc. v. West Publishing Co., 1997 WL 266972 (May 19, 1997). Neither the district court nor the reviewing Second Circuit found any copyright violation in this plan.

140 These problems include the provision of some rudimentary citator service, allowing the user to feel comfortable that a case has not been subsequently overruled; some form of digesting or annotation service to allow topical searching, to compliment the Boolean-based text-based search engine that would likely be a staple feature of such a site; and the elimination of all copyrightable elements of an opinion originally published by West.

141 While the Second Circuit's decision in Bender appears well-reasoned, it was only achieved by a two-to-one panel decision, with District Judge Sweet, sitting on the Second Circuit 
include federal district and bankruptcy court opinions in the database, a necessary step if the developer intended the database to be a viable alternative to Westlaw and LexisNexis. ${ }^{142}$

The alternative to such a battle would be to provide the cases using a neutral citation format. ${ }^{143}$ Such formats exist, and although the promise of neutral citation has gone largely unfulfilled as yet, perhaps now is the time for a concerted effort to press for the acceptance of neutral citation by America's state and federal courts, because they hold the key to opening up the law to all who want to read it.

\section{The Unrealized Promise of Neutral Citation}

The need for a neutral citation format ${ }^{144}$ has been recognized for some time. The Library Program Subcommittee of the United States Judicial Conference Committee on Automation and Technology proposed a neutral citation format in 1991 to serve as a stopgap format until citation to the appropriate West reporter was possible, ${ }^{145}$ and in 1994, the Technology Resource Committee of the Wisconsin State Bar proposed a neutral citation format that would allow the "courts, not private publishers, determine the citation" and would mean that " $[t]$ he state, and not private publishers, will 'own' the final text of the case law. It

by designation, filing a dissent to the majority opinion. And with other appellate and trial court decisions going the other way (see, supra n.109), a successful result for a commercial alternative legal information provider, while likely, is by no means preordained.

$142 \quad$ Federal district opinions are published by West in the Federal Supplement and Federal Rules Decisions Reporter series.' Bankruptcy opinions appear in the Bankruptcy Reporter. Perhaps because decisions issuing from trial courts have no precedential effect, they do not form part of the court opinion databases of most alternative legal information providers. Yet no federal court practitioner would consider litigating any issue relating to federal rules, for example, without having access to the trial court opinions in both of these reporter series', and any savvy state court practitioner knows that federal trial courts sitting in diversity often have valuable opinions about state court law, especially in areas in which state appellate courts have not ruled. Thus any legal information service that does not provide access to these opinions - not just those freely available on the internet but also those stretching back in time before such opinions were available from any source other than West - will be providing an incomplete service and a legal researcher will have to supplement research conducted on such a service with research conducted using more traditional means, thereby seriously limiting the value of such a site for serious legal researchers.

143 A parallel cite to the same case in its West-available format would likely be necessary. A reference citation alone, without internal pagination references, would likely not be objectionable to West.

144 The concept of a citation format that does not rely on publisher information as part of the citation goes under many names. I use "neutral citation format" here rather than "vendor neutral' or "medium neutral" or (the Bluebook's choice) "public domain" citation format because it is the most used, and perhaps also the simplest, term to describe this practice.

145 Wyman, supra n.112, at 259. The proposal met with opposition and was not adopted. Id. 
will encourage publishers to compete by the value that they add to opinions such as headnotes or search tools, rather than by preferred access to the text of case law." 146

Two heavyweights entered the neutral citation format debate in the mid-1990s; the American Association of Law Librarians ("AALL") in $1995^{147}$ and the American Bar Association ("ABA") in 1996.148 Yet even though both organizations endorsed the need for neutral citations, 149 there has been little movement towards acceptance of a neutral citation format. Indeed, although one federal circuit court of appeals has made a tentative step in favor of neutral citation, 150 the response of the federal judiciary to the ABA's neutral citation policies was so hostile that the Judicial Conference rejected the ABA proposal. ${ }^{151}$

146 Wis. State Bar Tech'y Resource Comm., Proposed Citation System for Wisconsin: Executive Summary, available at http://www.law.cornell.edu/papers/wiscite/wiscite.overview.html (last visited July 17, 2006). Citations to specific portions of opinions issued in Wisconsin since January 1, 2000 must use paragraph numbers rather than page numbers, and the public domain citation form for a case is the first choice for citation format. Wis. Sup. Ct. R. 80.02, cited by, ALWD Manual, at 442 .

147 AALL Task Force on Citation Formats, The Final Report of the Task Force on Citation Formats, 87 L. LiBR. J. 580 (1995)(“AALL Report”).

148 American Bar Association Special Committee on Citation Issues, Report and Recommendations (2006), available at http:// abanet.org/ftp/pub/citation/report.txt (last visited July 17, 2006). 149 The two West-employed members of the AALL Task Force dissented from the Task Force's Report and filed a separate dissent (AALL Report, supra n.147, 607-23), as did Frederick Muller, the New York State Reporter. Id., at 624-31.. Myrna Bennett, the Shepard's/McGraw Hill (the then publisher of LexisNexis) representative on the Task Force voted in favor of the Task Force's Report but asked that a position statement be included with the final Report. Id., at 606. The AALL Task Force's four recommendations were adopted by the AALL Board, recommendation 4 (to disband the Task Force and to create a standing committee in its place) at the AALL Annual Meeting on July 14, 1995, and recommendations 1, 2, and 3 at a special meeting on July 18, 1995. $I d$. at 578 . The ABA House of Delegates adopted a resolution recommending adoption of neutral citation (called "universal citation" by the ABA) in 1996. ("ABA Resolution") Available at http:// www.abanet.org/tech/ltrc/research/citation/resolution.html (last visited July 17, 2006).

150 The United States Court of Appeals for the Sixth Circuit "encourages the use of Sixth Circuit [generated, vendor neutral] citation by bench and bar when citing cases to or from the Sixth Circuit. While there will be no penalties for not using the electronic citation, the court and the bar will find it easier to retrieve cases from the various electronic publishers when the citation is used." Sixth Circuit Electronic Opinion Distribution and Citation Policy Changes, available at http:/ / www.aallnet.org/committee/citation/rules_6th.html (last visited July 17, 2006).

151 Colleen M. Barger, The Uncertain Status of Citation Reform: An Update for the Undecided, 1 J. APP. PRAC. \& PROCESS 59, 81 (1999). By contrast, the Department of Justice - or, at least, the Department of Justice as it was in 1997 - filed a strong statement in support of the ABA's neutral citation proposal, noting that "[b]ecause the competitive benefits from use of the recommended citation form should substantially outweigh the costs it imposes, the United States Department of Justice recommends that the federal courts adopt the ABA's recommended citation form." 


\section{A. The Rejection of Neutral Citation by the Federal Judiciary}

The federal judges who submitted comments in regards to the possibility of adopting a neutral citation format almost all rejected the notion; some because of aesthetic concerns, ${ }^{152}$ some rejecting paragraph numbering because "the court should be responsible for the text of the opinion and initial page numbering, ${ }^{153}$ some claiming that neutral citation formatting would be "cost-prohibitive" for sole practitioners and small law firms, and that it would "simply add[] needless and expensive complexity without adding much, if any, efficiency," 154 and some arguing that "it is highly inappropriate for a group outside the judicial branch to suggest that judges conform their work to certain standards... . To mandate that judicial opinions conform to a specific format, such as numbering every paragraph and including parallel cites to electronic publications, seriously invades judicial independence." 155

Judge Brinkema's concerns about judicial independence seem overstated. Federal judges are, after all, constrained in their freedom of action by all sorts of rules, most notably the federal rules of procedure, both civil and criminal, and of

Comments of the Department of Justice on the American Bar Association Citation Resolution, 1-2 (March 14, 1997). Available at http://www.hyperlaw.com/dojcitjc.htm. (last visited May 5, 2006). 152 See, e.g., Letter of the Honorable Stephen F. Williams, Judge, United States Court of Appeals for the District of Columbia Circuit, to the Appellate Court and Circuit Administration Division, (February 26, 1997), available at http://www.hyperlaw.com/jccite/004.txt, (last visited July 17, 2006), arguing that paragraph numbering of opinions "belongs to the civil law tradition and to decisions of the Federal Communications Commission, not to the common law"; letter of the Honorable Richard A. Posner, Chief Judge United States Court of Appeals for the Seventh Circuit, to the Honorable J. Owen Forrester, Chairman, Automation and Technology Committee, Judicial Conference of the United States (March 3, 1997), available at http:/ / www.hyperlaw.com/jccite/015.txt (last visited July 17, 2006), agreeing with Judge Williams' letter and arguing against adoption of ABA's neutral citation format because numbering paragraphs of judicial opinions would "disfigure and bureaucratize the opinion-writing process."

153 Letter of the Honorable Procter R. Hug, Jr., Chief Judge, United States Court of Appeals for the Ninth Circuit, to the Administrative Office of the United States Courts Appellate Court and Circuit Administration Division, (March 14, 1997), available at http://www.hyperlaw.com/jccite/400.txt (last visited July 20, 2006).

$154 \quad$ Letter of the Honorable David D. Dowd, Jr., Judge, United States District Court for the Northern District of Ohio, to the Administrative Office of the United States Courts Appellate Court and Circuit Administration Division, (February 26, 1997), available at

http://www.hyperlaw.com/jccite/016.txt (visited July 20, 2006). Judge Dowd's concerns fails to consider, of course, the tremendous expense associated with Westlaw or LexisNexis use, or with maintaining a print library of legal research materials. The costs associated with either of these options often makes them "cost-prohibitive" for sole practitioners and small law firms.

155 Letter from the Honorable Leonie M. Brinkema, Judge, United States District Court for the Eastern District of Virginia, to Joan Countryman, Appellate Court and Circuit Administration Division, Administrative Office of the U. S. Courts (March 5, 1997), available at

http://www.hyperlaw.com/jccite/006.txt (last visited May 11, 2006). 
evidence. Federal district judges, like Judge Brinkema, ${ }^{156}$ are also required to follow decisions from the Supreme Court of the United States, the precedential opinions of the Circuit Court of Appeal in which they are located, ${ }^{157}$ decisions from the highest state court when they have diversity jurisdiction, as well as all the relevant legislative enactments that govern everything from their jurisdiction to hear cases to the specific rules they must apply in deciding cases.

But the problems with Judge Brinkema's position run even deeper, because in fact, all federal judges are required to follow West's citation format in opinions published in West reporters. If they do not, West editors will alter the opinions after they are handed down, but before publication in a West reporter, so as to conform them to West's citation style. This requirement cannot be found in any rule or statute, but its effect can be seen when comparing a judge's original opinion with the version published by West.

For example, Judge Brinkema's decision in NBC Universal, Inc. $v$. NBCUniversal.com ${ }^{158}$ cites to two Supreme Court cases to explain that a federal court should abstain from exercising its jurisdiction only under "extremely rare circumstances," 159 and only when another court has exercised jurisdiction over the res at issue. ${ }^{160}$ Whether intentionally following The Bluebook's instruction to cite only to United States Reports or not, ${ }^{161}$ Judge Brinkema's decision omits any parallel citation to the Supreme Court Reporter or to the United States Supreme Court Reports, Lawyer's Edition.

Yet in the version of Judge Brinkema's opinion that appears in the Federal Supplement, Second Series, ${ }^{162}$ the parallel citations to both unofficial reporters have been added to both cases. ${ }^{163}$ The unsuspecting reader might therefore

\footnotetext{
156 Judge Brinkema sits on the Eastern District Court of Virginia, Alexandria division.

157 The Fourth Circuit in Judge Brinkema's case.

$158 \quad$ No. 1:05cv268 (E.D. Va. filed July 14, 2005).

159 Id. at 4, citing Colorado River Water Conservation Dist. v. United States, 424 U.S. 800, 813, 821 (1976).

160 NBC Universal, Inc. v. NBCUniversal.com, No. 1:05cv268, 4-5 (E.D. Va. filed July 14, 2005), citing Princess Lida of Thurn \& Taxis v. Thompson, 305 U.S. 456, 466 (1939).

161 Bluebook, supra. n.19, Rule 10.3.1 \& table T.1. The Bluebook allows for no interpretation. "Cite to U.S., if therein; otherwise, cite to S. Ct., L. Ed., or U.S.L.W., in that order of preference." Id., table T.1. The ALWD Manual gives more discretion, noting that " $[\mathrm{m}]$ any attorneys prefer to include a parallel citation that includes the United States Reports, the Supreme Court Reporter, and sometimes the Lawyers' Edition - in that order. Although not preferred, this citation format is permitted." ALWD Manual, supra n.20, at 79, Rule 12.4(c)(2).

$162 \quad 378$ F.Supp. $2 d 715$ (E.D.Va. 2005).

163 Id. at 717, citing Colorado River Water Conservation Dist. v. United States, 424 U.S. 800, 813, 821, 96 S.Ct. 1236, 47 L. Ed. 2d 483 (1976); Princess Lida of Thurn \& Taxis v. Thompson, 305 U.S. 456, 466, 59 S.Ct. 275, 83 L.Ed. 285 (1939). Interestingly, West does not alter the citations to statutory authority. Compare NBC Universal, Inc. v. NBCUniversal.com, No. 1:05cv268, 1 (E.D.
} 
conclude that Judge Brinkema was one of those judges she described as including parallel cites in her opinions and not following The Bluebook, ${ }^{164}$ rather than the victim of the very invasion of judicial independence about which she protests. 165

\section{B. West's Opposition to Neutral Citation}

West was vociferous in its opposition to neutral citation format, perhaps because it correctly identified citation as one of the most important impediments to the development of an alternative to West-based legal information. West had two members on the AALL Task Force on Neutral Citation Formats ${ }^{166}$ who combined on a dissent to the Task Force's recommendations that neutral citation formats should be adopted. ${ }^{167}$

In addition to their disparagement of neutral citation as the "nowhere" citation format, 168 the West-employed task force members raised numerous objections to

Va. filed July 14, 2005) (citing to the Anti-cybersquatting Consumer Protection Act, 15 U.S.C. \& 1125, and the Lanham Act, 15 U.S.C. § 1051) with NBC Universal, Inc. v. NBCUniversal.com, 378 F.Supp. 2d 715, 716 (E.D.Va. 2005)(same). Those same statutory authorities, however, receive citations to the West-published United States Code Annotated in the West-drafted headnotes to the case. Id. at 715.

164 Letter from Leonie M. Brinkema, United States District Judge, Eastern District of Virginia, to Joan Countryman, Appellate Court and Circuit Administration Division, Administrative Office of the U. S. Courts (March 5, 1997), available at http://www.hyperlaw.com/jccite/006.txt (last visited May 11, 2006).

$165 I$ Id. It is possible, of course, that Judge Brinkema was unaware that West makes these editorial changes. Federal judges are busy people and have little, if any, time to re- read opinions they drafted some time previously when they come out in print. One imagines that a judge as sensitive to judicial independence as Judge Brinkema would be horrified to discover that her opinions are receiving ex post facto editing to make them non-Bluebook compliant.

166 Donna Bergsgaard (Manager, Reporter-Digest, West Publishing Co.), and Bill Lindberg (Manager, Educational Services and West Academic Programs, West Publishing Co.) AALL Report, supra n.147, at 582. Bergsgaard and Lindberg left no doubt that their dissent was also West's official position when they identified themselves as being employed by the West Publishing Company in the title of their dissent. Id. at 607.

167 Id., at 607-23. The West representatives did not oppose the Task Force's recommendation that it be disbanded and replaced by an AALL Committee. Id. at 621.

$168 I$ Id. at 612-13. Bergsgaard and Lindberg adopted this term to dramatize the fact that a neutral citation would not, at present, point a researcher to a location where the case could be found and read. "The citation accurately identifies the specialized court issuing the opinion, but provides absolutely no clue that helps the researcher to identify the publication, CD-ROM, or online service where she can actually find the opinion. It is truly a citation to nowhere (hereinafter "Nowhere Cite")." Id. at 613 (emphasis in original). Bergsgaard and Lindberg are, of course, correct that, at present, a neutral citation would not take a reader to a particular vendor's publication of a case, although since that is the fundamental principle of a vendor neutral citation, their employment of this mocking phrase - strangely out of place in the world of academic debate - seems to be more about the fact that neutral citations would not help a researcher to find the case in a West-published version of the case. This criticism also ignores the possibility of a future publisher employing a neutral citation format to identify cases, and 
the adoption of neutral citation formats, among them their contentions that: "uniformity need not be achieved through government intervention;" 169 neutral citation "promotes lack of uniformity;" 170 neutral citation is "impractical when applied to regional reporters;" 171 the AALL task force failed to consider a "needs assessment from the bench and bar perspective;" 172 neutral citation would require "radical and costly changes in judicial administration in many states;" 173 neutral citation is "unworkable for locating cases in looseleaf topical reporting services, legal newspapers, and many other compilations;" 174 neutral citation

assumes (almost certainly incorrectly) that West would not add neutral citations to the cases it publishes were neutral citation formats to be required by courts.

169 Id. at 610. Bergsgaard and Lindberg contended that "any change in citation practice should be based on the needs of the legal profession" and that the marketplace, not government, should dictate any changes in citation format. Id. In this contention they echo, almost word-forword, the opinions expressed by Robert Berring in an article published the same year as the Bergsgaard and Lindberg dissent. Berring, supra n.15, at 635 ("[Moving the American legal information system into a new era] should not mean turning over a system that works quite well to the good offices of the government in any of its manifestations. The current system works. The market will let us know when a new one is ready.") The problem here, of course, is the market imbalance caused by West's preeminent role in it. See, infra n.183.

170 AALL Report, supra n.147, at 613. This contention is predicated on the dissimilar approaches taken by different states to the publication of cases in 1995, when the report was written, and particularly on their perception that taxpayers would be unwilling to fund "a centralized electronic archive of judicial opinions." Id. The changes in the legal information world since 1995 render this issue moot today.

$171 I d$. at 614. In essence, the authors here do little more than defend the ubiquity of West's National Reporter System, and they "vehemently object to the majority's cavalier suggestion that the proposed citation format can be accommodated by forcing users of this simple, understandable system to engage in complicated 'lookups' before they can pull cases from the National Reporter System shelves." Id.

$172 I d$. at 615. This is not so much a criticism of neutral citation, of course, and more a criticism of the task force's methodology.

$173 I d$. at 617. Bergsgaard and Lindberg argued here that neutral citation format would "force the states to adopt centralized Clerk of Court offices" (id.) without explaining why. If it is the case that a centralized numbering system would be required in order to generate neutral citations, Bergsgaard and Lindberg fail to consider whether such a step could be taken by simpler administrative procedures than an entire overhaul of a state's clerk's office. As to cost, the Conference of Chief Justices reported, in 1999, that "[t]hose jurisdictions that are adding sequential opinion numbers or paragraph numbers report that no additional costs are associated with these activities. Numbering opinions and paragraphs is a mechanical process. Several states have developed macros or software techniques for adding the necessary numbers, and are often willing to share these tools with other jurisdictions." Conference of Chief Justices, Report of the Committee on Opinions Citation, 6 (1999). Available at http://ccj.ncsc.dni.us/finalrpt.pdf (last visited July 21, 2006).

$174 \quad I d$. The problem with the authors' contention here is that present citation form is incompatible with these sources as well. In order to make their point, they set up a straw argument - that "[a] citation format that requires all cases to be reported and arranged according to jurisdiction and chronological date of decision would completely tie the hands of publishers who wish to add value to their publications ... by linking related cases or reporting cases shortly after they are decided...." (id. at 618) - and then contending that neutral citation formats that 
"does not eliminate the need for parallel citations;" 175 and "paragraph numbering raises numerous questions that still require answers." 176

But although the objections raised by the two West dissenters to the tasks force's all have ready answers, and despite the endorsement of both the AALL and the ABA for neutral citation format in the mid 1990s, little has happened to make neutral citation a reality. ${ }^{177}$ Some jurisdictions have passed rules requiring or permitting the use of neutral citations, ${ }^{178}$ but the use of neutral citations cannot be said to be widespread.

Recognizing that momentum had been lost in the struggle to achieve universal adoption of neutral citation, the ABA's Standing Committee on Technology and Information Systems filed a report with the ABA's House of Delegates calling on the ABA to "once again take the lead in developing a universal citation format

fail to identify such publications would make it "exceedingly difficult to locate such cases." Id. In fact, that is precisely the situation that obtains under the present citation system as well. The publishers of topical reporting services live on the margins of topicality, and once a case is reported in the National Reporter System, the vitality of a case in a looseleaf reporter is, for most purposes, at an end. The almost immediate access permitted by the internet does indeed pose a serious problem for the publishers of topical reporters, but it is access, not citation format, that causes the danger here.

$175 I d$. Bergsgaard and Lindberg might be correct here, but how this is a criticism of neutral citation format defies understanding.

$176 I d$. at 619. Once again, although perhaps true, the questions Bergsgaard and Lindberg raise hardly seem sufficiently grave to abandon the concept of neutral citation. They ask, for example, "[w]hat are the potential costs of numbering paragraphs in judicial opinions?" (id.) and observe that it might be costly to hire clerks to number the paragraphs in judicial opinions, and note that "there exists the very real possibility that unintentional changes will be made to the substance of the opinions themselves." Id. Yet they themselves acknowledge that software (or, as Bergsgaard and Lindberg write it, "software" (id. (emphasis in original))) will likely perform the numbering function, and while it is, of course, true that unintentional changes will be made to original opinions, any number of horrible fates might befall a judicial opinion subjected to West's editorial practices if the standard is that of "possible" events. In any case, the Report of the Chief Judges' Committee on Opinions Citation (supra n.173) appears to answer most, if not all, of Bergsgaard and Lindberg's questions.

177 Both The Bluebook (Rule 10.3.3) and the ALWD Manual (Rule 12.16), provide neutral citation formats, but only as an alternative to the preferred, familiar, reporter-based, citation format.

178 See, ALWD Manual Appx. 2 (indicating that Colorado, Louisiana, Maine, Mississippi, Montana, New Mexico, North Dakota, Oklahoma, South Dakota, Utah, Vermont, Wisconsin, and Wyoming have all adopted some form of neutral citation for their opinions, as have the United States Court of Appeals for the Sixth Circuit, and the United States District Court for the District of South Dakota.). The ABA's website indicates that Arizona has also adopted neutral citation, but notes that both Arkansas and Tennessee have specifically rejected neutral citation as a viable format. Available at http://www.abanet.org/tech/ltrc/research/citation/uscourts.html (last visited July 21, 2006). 
that can be adopted by all American jurisdictions[,]"179 and recognizing that new technologies such as extensible markup language ("XML") hold new promise for the development of a standard vendor-neutral citation format. ${ }^{180}$ But although the ABA's House of Delegates adopted a resolution in February, 2003 approving the committee's report, ${ }^{181}$ the adoption of neutral citation is no more universal in 2006 than it was in 2003.

One possible reason for the inertia preventing acceptance of neutral citation might be the market pressures bearing down on the issue. Put simply, neutral citation is unlikely to be accepted by the legal community until the citation points a reviewer to a location where a case can be found, 182 yet no commercial publisher is likely to invest the time and effort necessary to develop a database of common law materials, linked to neutral citations, without some assurance that these materials will be accepted and used by the legal community. ${ }^{183}$ This vicious cycle virtually ensures West and LexisNexis' continued domination of the legal information market. 184

179 American Bar Association Standing Committee on Technology and Information Systems, Report: Universal Citation Facilitation, available at http://www.abanet.org/tech/ltrc/research/citation/2003report.html (last visited July 21, 2006). $180 \quad$ Id.

181 Available at http://www.abanet.org/tech/ltrc/research/citation/2003resolution.html (visited July 21, 2006).

182 Bergsgaard and Lindberg's "Nowhere Citation" problem.

183 The "market" argument ignores West's huge competitive advantage over any potential competitor, brought about by its publication of the National Reporter System and the lower federal court decisions. This advantage has "skewed any 'natural' market response to new citation forms. Thus, one cannot suggest that the market dictates citation form because current citation requirements prevent it from doing so. If the courts gave up citation requirements to specific sources such as West reporters and adopted the 'open rule' of citation, then perhaps the market would eventually come to favor a particular citation form." Wyman, supra n.169, at 271. It also ignores West's ability to dominate the market by purchasing potential competitors, as it did in 2001, when it purchased the free legal information website "Findlaw," "one of the most popular portals for accessing free legal information on the Internet." Svengalis, supra n.45, at 14 . Although not disclosed, the purchase price was rumored to be $\$ 37$ million. News This Week Ticker, NAT'L L. J., Jan. 15, 2001, at A4. There are, of course, niche players in the legal information market, such as Casemaker, Loislaw, and Versuslaw. Each of these alternative databases, however, has limitations that make them inadequate substitutes for full-content databases like Westlaw and LexisNexis. In each case, for example, their historical coverage is limited and they lack coverage of federal district court opinions. Any comprehensive legal search undertaken using these services must be supplemented by research using more traditional resources, either using Westlaw or LexisNexis or West's print-based research tools. Moreover, neither Versuslaw nor Loislaw is free, and Casemaker, although for all purposes "free" to the user because the fee for access is part of a user's bar membership fee, is, by its pricing structure, limited to members of the bar, and is unavailable to members of the public and non-legal academics.

184 This likely explains why West so favors the "market" solution. See, supra n.169. Put simply, West has proven itself to be a highly skilled operator in the market. West's success has 


\section{America's Law Schools And A Potential Solution to Neutral Citation Inertia}

The solution to this seemingly intractable situation, as with most vicious cycles, is to change the way in which the problem is viewed. In this case, in order to liberate the law from its commercial shackles, we should stop thinking of common law cases as a commodity, to be bought and sold (or, increasingly, to be licensed $\left.{ }^{185}\right)$, and should instead reconceptualize cases as elements of social narrative, each case part of a story the judicial system tells about this country. ${ }^{186}$

been constructed on shrewd business decisions calculated to neutralize competition and dominate the legal information market. See, Berring, supra n.15, at 623-24. ("[The National Reporter System] is the product of a series of editorial and market decisions and a survivor of a highly competitive marketplace.... John B. West had an original way of doing things, much criticized at the time, but ultimately successful." While numerous competing companies offered, in essence, the same information, it was West's addition of digesting information, allowing attorneys to conduct interjurisdictional research, as well freeing attorneys from conducting their own digesting of cases issued in their home jurisdiction, that allowed his company to take control of the market. In fact, the Supreme Court had acted to prevent the commoditization of the law in Wheaton v. Peters, 33 U.S. (8 Pet.) 591, 668 (1834), when it held that "no reporter has or can have any copyright in the written opinions delivered by this court. ..." But West's "value added" digesting service, in essence, cut an effective detour around the Supreme Court's decision.

185 A purchaser of a West National Reporter Series volume buys a book which sits on a shelf and is, in essence, immutable (albeit subject, of course, to normal wear and tear, acts of vandalism, and natural disasters such as fire and water damage). The purchaser can be said to own that volume, although not, of course, the law contained in that volume. By contrast, a user of Westlaw or LexisNexis only has a license, not an ownership interest, in the data stored in the database, and the user retrieves data subject to that licensing agreement.

186 An example of the way in which this sort of reconceptualization can liberate information from the narrow confines of its origins is the "Proceedings of the King's Commission of the Peace and Oyer and Terminer, and Gaol-Delivery of Newgate, held for the City of London and the County of Middlesex, at Justice-Hall, in the Old Bailey" ("Proceedings"). The Proceedings are a collection of synopsized reports of criminal trials conducted at the Old Bailey, published sporadically from 1678 until 1918, with extensive coverage in the 18th Century. Despite numerous potential traps for the unwary legal historian, the Proceedings constitute "probably the best account we shall ever have of what transpired in ordinary English criminal courts before the later Eighteenth century." John Langbein, The Criminal Trial Before the Lawyers, 45 U. CHI. L. REV. 263, 271 (1978). Prior to the digitization of the Proceedings, historians wanting to work with them had to travel to several different libraries because no single collection of the entire set of Proceedings was available. See, JOHN LANGBEIN THE Origins Of ADVERSARY CRIMINAL TRIAL at 182-83, n.15 (2003)(describing work on the Proceedings at the Bodleian Law Library (Oxford), the British Library, the Guildhall Library (London), the Harvard Law School Library, and the University of Chicago Law School Library. The Proceedings from 1674 to 1834 are now available on-line at http:/ / www.oldbaileyonline.org/ (last visited July 23. 2006). The oldbaileyonline project serves as a shining example for the capabilities of XML databases in which the ABA has placed so much hope. See, infra at n.165 and accompanying text. The collection is full-text searchable, allowing the researcher to search for specific terms ("murder," "highway robbery," and so on), either across the entire database or within certain narrower parameters selected by the researcher; one can, for example, search for cases mentioning murder committed by women 
When viewed in this non-commercial light, a possible solution emerges; rather than another for-profit publisher seeking to make money from publishing the law, what is needed is a publisher with no profit motive, but that still has the resources to commit to such a project, and which has a scholarly interest in, and intellectual commitment to, the law for its own sake. ${ }^{187}$ The most logical candidate for such a role is a consortium of American law schools, working together to find, edit, and publish American common law for the benefit of all.

According to the American Bar Association, there are 193 approved, or provisionally approved, law schools in this country. ${ }^{188}$ Each of these law schools must offer its students "substantial opportunities for ... student participation in pro bono activities." 189 The need for an eleemosynary component to an American legal education is therefore a mandatory element of every ABAaccredited law school program, thereby codifying the law school's role as a "public good."190 And while law schools provide vital pro bono services in the

during the period 1700-1750. The liberation of the data in the Proceedings is, therefore, much like the liberation of legal data permitted by the Lexis database when it offered an alternative to the West digesting approach to legal research. To celebrate this project, the University of Hertfordshire conducted a conference, Tales From The Old Bailey: Writing A New History From Below, in 2004. One thread that ran through the conference presentations was how data that once been barely accessible, and known about by, at best, an extremely limited number of legal historians specializing in the development of criminal law, criminal procedure, and evidence, was now available and of interest to a broad spectrum of people, including social historians, sociologists, and non-academics who had a general interest in the 18th Century. As one conference participant remarked, any author setting a work of fiction in England during the 18th Century now had the perfect resource with which to conduct research into the period. The digitization of the Proceedings had, therefore, allowed the reconceptualization of the information contained within the collection, and had allowed a broad group of researchers who might otherwise have had no access to the materials to conduct a limitless number of searches keyed to their specific interests. The promise realized by this digitization project - conducted, it should be noted, by two British Universities (the Humanities Research Institute of the University of Sheffield and the Higher Education Digitization Service of the University of Hertfordshire) and funded by the British Arts and Humanities Research Council, the New Opportunities Fund, and the Enrich UK Fund (funded by money from Britain's National Lottery) - is something to which a legal information digitization project could aspire.

187 And the resources required would be considerable. Even assuming that the internet would be the preferred delivery mechanism, any publisher would require a large number of skilled editors and reviewers to make sure the database is complete and up-to-date, ensure quality control, and develop and maintain even rudimentary finding tools and citator service. 188 Available at http://www.abanet.org/legaled/approvedlawschools/approved.html (last viewed July 21, 2006).

189 American Bar Association Section of Legal Education and Admissions to the Bar, Standards for Approval of Law School, Section 302(b)(2). Available at http:/ / www.abanet.org/legaled/standards/chapter3.h (last viewed July 21, 2006).

190 Syracuse University's Chancellor, Nancy Cantor, has used this phrase to describe the role of the university in contemporary society. See, e.g., Nancy Cantor, University as Public Good: Exploring the Soul of Syracuse. Available at http://soulofsyracuse.syr.edu/explore/ (last viewed July 21, 2006). 
communities where they are located, there can be no more significant pro bono activity than making this country's law available to its citizens.

\author{
Law schools are ideally suited for this endeavor because they are, for the most \\ part, ${ }^{191}$ non-profit organizations with no fiduciary obligation to shareholders or \\ owners and whose only interest is the study of law and its role in society. ${ }^{192}$ \\ Their involvement would permit the law to be published free for all - lawyers, 193
}

191 There are two ABA-accredited for-profit law schools; Florida Coastal School of Law and Western State University College of Law. Concord University School of Law is also a for-profit endeavor but it has not been accredited by the ABA.

192 Several law schools have independently accepted the challenge of offering portions of American law to the general public. Cornell Law School's "Legal Information Institute," available at http:/ / www.law.cornell.edu/ (last visited July 26, 2006), offers federal and state legislative materials, and acts as a portal through which a researcher can access the web sites of federal and state appellate courts. Washlaw, a product of Washburn School of Law, available at http:/ / www.washlaw.edu/ (last visited July 26, 2006), and Emory School of Law's Macmillan Law Library Electronic Reference Desk, available at http://www.law.emory.edu/erd/index.html (last visited July 26, 2006), are two other excellent examples of portal sites allowing access to various federal and state materials. All of these approaches are limited by several significant factors, however: because they rely on the various state and federal jurisdictions for the actual data, there is no consistent presentation of material, searches are non-interjurisdictional, and coverage is limited to what coverage the jurisdiction has made available, making these resources unhelpful for anything approximating full-blown legal research of an issue.

193 Whether or not a freely-available database of common law opinions would be appealing to lawyers is difficult to say. On the one hand, the database would likely lack refinements such as digested search capabilities, and would identify cases according to a non Bluebook-like citation system. On the other hand, the capability to conduct unlimited searches for no charge would doubtless be appealing to solo practitioners, small law firms, and lawyers conducting pro bono and low fee representation. It is likely that even larger law firms would be drawn to legal information that could be obtained without billing clients - either directly, through a per-access fee, or indirectly, through flat-rate access fees accounted for by the built-in overhead allowance that constitutes part of a lawyer's hourly billing rate. Certainly this was Robert Berring's belief in 1995. Berring noted that any move to make the law freely available "will benefit lawyers more than anyone else. By far, the greatest use of legal information is made by lawyers in various guises, mostly to make money.... One would have to be incredible naïve to think that such a program will end up being designed for the average citizen." Berring, supra n.15, at 627. Berring described this as a "very real political problem" (id.) because he was thinking in terms of a government-funded program as the model for providing free access to the law; certainly an academic-based program would not raise the same concerns. Berring's concerns might not be valid, even were the government to be the medium through which the law became freely available to all citizens. He ignores, for example, the significant number of lawyers who act in the public interest, and who need access to the law for reasons other than to "make money." But it is unclear whether larger for-profit law firms, and their clients, should not have free access to the law, even if profit is their goal. Publicly-traded corporations, for examples, are required by government regulations to make available a substantial amount of freely-available information which can be used by anyone to make investment decisions; in essence, individuals and corporations "make money" every day based on free information made available to them by government mandate. 
judges, ${ }^{194}$ non-legal academics, ${ }^{195}$ pro-se litigants, ${ }^{196}$ and the curious; ${ }^{197}$ they have a large number of intelligent and motivated students to work on the numerous tasks involved with creating and maintaining a database of this nature; their relative stability would allay concerns that those who began to rely on free access to the law could be left stranded if the service were to be discontinued; and they have a large number of teachers who would likely be willing to supervise the students' work.

The project would be a large one, 198 and would require some substantial investment in hardware and time. ${ }^{199}$ Most significantly, however, it would require the use of a universal neutral citation format to identify cases. ${ }^{200}$ It might

194 Judges would likely be the least interested in using such a service, especially since many court systems have access to Westlaw and/or LexisNexis at a subsidized rate.

195 One of the most significant deficits caused by the flight from print-based legal information materials will be the constriction of access to the law to those academics who are not entitled, by virtue of their affiliation to a law school, to "free" time on Westlaw and LexisNexis. Although some services, such as LexisOne and Findlaw, allow such academics access to some law, the ability of anthropologists, historians, sociologists, psychologists, and other scholars to study and write about the law would be severely limited without the free publication of the common law.

196 There are, of course, dangers in allowing pro se litigants access to the law, as discussed supra at nn. 56-60 and accompanying text.

197 Hard as it might be for lawyers to believe, there is interest in the non legally-trained general public in having free access to court opinions. For a sample of opinions expressing this phenomenon, see, e.g., Comments of General Public: Comments to Judicial Conference re Citation Reform, available at http:/ / www.hyperlaw.com/jconf.htm\#survey (last visited July 21, 2006). 198 The project might be large, but its scope is not inconceivable. Google's Library Project, for example, demonstrates that internet publication of large-scale scanning projects is possible. Google is working to scan the book collections of the University of Michigan, Harvard University, Stanford University, the New York Public Library, and Oxford University. Those books that remain in copyright will have only small portions displayed online, but those books that are no longer in copyright will be available for reading or downloading. See, http:// books.google.com/googlebooks/common.html (last viewed July 22, 2006).

199 In addition to the logistical complexities involved in developing a consortium of law schools to conduct this project, it would be necessary to develop techniques for ensuring that the portions of cases over which West holds a copyright were not reproduced, a method of automating the data entry process so that elements such as citations and formatting could be added as efficiently and accurately as possible, and reliable error-checking protocols that would ensure the accuracy of the material offered to the public.

200 The neutral citation format is, of course, necessary to avoid any potential copyright entanglements with West. The universality of the format is crucial, for the reason Bryan Garner criticized the Maroonbook's proposed citation format back in 1990. Supra, n.67. Garner noted that by discarding a universal citation format, the Maroonbook's editors could have thrown the legal research world into chaos., because computers require precise instructions before they can find information. Garner, supra n.82, at 194. And while experience with Westlaw and LexisNexis teaches that computers can be programmed to accept a surprising number of variations on a citation theme (they will, for example, accept "F. Supp. 2d," "f supp 2d," fed supp 2d," and "fedsupp $2 \mathrm{~d}$ " as acceptable search requests for the Federal Supplement, Second Series), a free-for- 
seem controversial to propose that the publisher, rather than the court, provide the citation format for cases. ${ }^{201}$ Yet the reaction of federal judges to the ABA proposal suggests that courts will take, at best, an inordinate amount of time to be persuaded that they should lead this effort and, in any case, West's adoption of its own reporter names and page numbers gives ample precedent for allowing a publisher to select its own preferred citation format. This would, at a stroke, eliminate the most serious barrier to the adoption of neutral citation format. ${ }^{202}$

While there are significant issues to address, and several problems to overcome, none seem insoluble, and the benefits of freeing the law from its commercial shackles, and making it available without cost to anyone who wants it, are incalculable. Such a project would not, of course, eliminate the role West and LexisNexis play in providing case law with sophisticated finding tools, but it would give those who cannot afford access to those expensive commercial databases the chance to locate, read, and use law that might be of interest or value to them, whatever their purpose might be. And it would be proof that the law is for everyone, not just for lawyers; surely a message that cannot be emphasized enough.

all citation format, such as that contemplated by the Maroonbook, would be problematic. And while Garner perhaps exaggerates the danger in order to make his criticism more forceful, his point is still valid; universality, with some margin for error, is important for a citation format when the information is stored in a computer's database.

201 The AALS Task Force on Citation Formats recommended that "jurisdictions considering change to a neutral citation form" should use its proposed format. AALL Report, supra n.147, at 578. And the ABA recommended that "all jurisdictions adopt a system for citation to official case reports" that is neutral in format. ABA Resolution, supra, n.149. Commentators have also emphasized the role of the courts in adopting neutral citation format. See, e.g., Wyman, supra n.112, at 271 (" . . it is up to the courts - whether seen as 'Big Government' involvement or no to sort out citation requirements and adapt them to evolving technological needs.") See also, Berring, supra n.15, at 622 ("One of the most potent arguments about the present [legal information] system is that legal information is nothing more than the law itself, and that the law itself belongs to everyone. .. . Accordingly, the law should be made available at no cost, or at least at very law cost, to all. ... Depending on how 'all' is defined, this logic suggests two sets of proposals. If 'all' refers to each person, then the goal of providing free or low-cost information to all presumably means that the government should be the provider.")

202 The question of parallel citations would, of course, remain, and would have to be resolved not just for the initial case citations that appear at the beginning of a decision but also for the internal citations to other cases that appear in the body of nearly all decisions. The solution to this problem would likely require the creation of a database of all case citations in both West and neutral citation formats. Part of the process of converting decisions from West to neutral format would be the addition, likely by software, of a parallel neutral citation for every cited case within the body of a decision. 


\section{Conclusion}

The journey from citation format to non-commercial distribution of the law seems to be a long one. Yet the constriction of access to the law can be traced directly to the bibliographical method lawyers use and have used since The Bluebook became the standard for legal citation. The ALWD Manual, although superior to The Bluebook in its organization and presentation of material, offers essentially the same citation formats for American case law as its competitor and is therefore no improvement on it, at least in terms of opening up access to legal information. ${ }^{203}$ Both citation manuals, by their emphasis on West-published case law, continue to provide support for West's continued domination of the legal information market.

There is no reason for either The Bluebook or the ALWD Manual to change their position until a viable competitor appears on the scene to offer an alternative to the West/LexisNexis duopoly. And yet no viable competitor is likely to be able to offer such an alternative without a citation system in place that allows it to compete with West without treading into some thorny copyright issues directly related to citation. Although the American Bar Association and the American Association of Law Librarians have offered neutral citation alternatives, law students, lawyers, courts and legislatures have demonstrated little interest in following anything other than the Bluebook-style citation format with which they are familiar.

This situation, while troubling to those who would prefer to see the law as something other than a bottom-line commodity, has not been critical until recently; cases have been, and continue to be, published in bound reporters that can be searched using digests and other print-based finding tools. ${ }^{204}$ But the

203 Christine Hurt predicted that the ALWD Manual "has a high probability of dethroning the resident monopolist." Hurt, supra n.79, at 1260. But the ALWD Manual is not, in Hurt's descriptive phrase, a "[b]etter Bluebook [m]oustrap in the [a]ge of [e]lectronic [m]ice." Id., at 1257. Rather, it is the same mousetrap with some superficial alterations; a green cover instead of blue, different presentation style for the citations, and so on. And, in the immortal words of Judge Samuel Kent - who was writing in a very different context - ". . at the end of the day, even if you put a calico dress on it and call it Florence, a pig is still a pig." Bradshaw v. Unity Marine Corp., Inc., 147 F.Supp 2d 668, 671 (S.D.Tex. 2001). This is not in any way to disparage the ALWD Manual or its creators. The Manual achieves its purpose of providing a better teaching alternative to The Bluebook in brilliant fashion and is, considered on its own terms, a triumph. It is, however, to suggest that the ALWD Manual's purpose was too limited, and that when viewed as an impediment to the open access to case law, it fairs no better than The Bluebook.

204 This research method is perfectly adequate for those researching the law as law; in other words, for those seeking to use cases to support or contradict a legal position. But for non-legal academics, such as historians, who might be interested in exploring relationships between cases in ways not contemplated by West's Langdellian division of cases into legal topics and subtopics, 
price of printing reporters and digests, and the cost of maintaining a fullystocked library of these materials, combined with the availability of the Westlaw and LexisNexis databases, means that it is likely we will soon no longer have upto-date print materials on which to rely for legal research. And while this might not affect large law firms, it will have serious ramifications for pro se litigants, solo practitioners, small law firms, pro bono representation, and public interest litigation, not to mention those members of the public who, for whatever reason, want access to the common law.

Waiting for neutral citation format to become accepted in the legal community, thereby encouraging commercial competition to Westlaw and LexisNexis, is a failed strategy. Ten years have passed since neutral citation resolutions were passed by the ABA and the AALS and there has been little significant progress in the adoption of a universal neutral citation format. The time has come for a change in the way the law is published, and since it seems unlikely that a commercial approach is realistic, under the current market situation, a noncommercial publisher seems to be the best hope for such a change to be implemented.

A consortium of America's law schools seems to be the perfect candidate for such an ambitious undertaking. Law schools possess the numbers, the skills, and, perhaps most importantly, the calling to carry out this project and to make sure that the common law is available free-of-charge to anyone who wants it. And once such a database was available, and once it had been demonstrated to be accurate and dependable, the legal and judicial communities would likely embrace it and the neutral citation format used to identify its cases. That might be disappointing to those who make a fetish of Bluebook citation form, but it would be a liberation for the rest of us, and for the law itself.

digest searching is relatively unhelpful. For such academics, a full-text search capability linked to an on-line database of case law would be much more helpful. 